Z. vergl. Physiologie 68, 345--384 (1970)

(C) by Springer-Verlag 1970

\title{
Innervation of the Receptors Present at the Various Joints of the Pereiopods and Third Maxilliped of Homarus gammarus (L.) and other Macruran Decapods (Crustacea)
}

\author{
W. Wales, F. Clarac, M. R. Dando and M. S. Laverack \\ Gatty Marine Laboratory and Department of Natural History, \\ University of St. Andrews, Scotland.
}

Received April 9, 1970

Summary. This paper gives a full account of the number and structure of the chordotonal organs present at all joints between the coxopodite and dactylopodite of the pereiopods and $3 \mathrm{rd}$ maxilliped of the macruran Homarus gammarus $\mathrm{L}$. ( $H$. vulgaris M. Ed.). Some comparative data is supplied for other macruran decapods. As the form of the receptors depends to some degree upon the structure of the joint we have included details of musculature, planes of movement and degrees of freedom at each of the joints.

The third maxilliped has a smaller number of ehordotonal organs than the poreiopod, in particular at the mero-carpopodite and carpopodite-propodite joints where only one organ is present. In some species the propodite-dactylopodite organ is absent from this limb.

The electrical activity recordable from the receptors in the 3rd maxilliped shows considerable differences from the corresponding receptors in the pereiopod.

The structure of the carpopodite-propodite joint of both limbs is discussed in detail as this joint differs greatly from that of the Brachyura. In the 3rd maxilliped and 2nd pereiopod three muscles are present. In the latter the joint is capable of rotation about the longitudinal axis but the third muscle does not appear to produce this rotation. $A$ small number of units in the $\mathrm{CP}_{2}$ receptor respond to rotation.

A receptor is described in the basipodite of the pereiopod and 3rd maxilliped situated just proximal to the plane through which the limb breaks at autotomy or autospasy. This receptor does not monitor joint movement and may detect cuticular strain, thus preventing accidental autotomy of limbs. A similar receptor has been observed in Carcinus.

Cuticular receptor structures (CAP organs) are described as present at the M-C and C-P joints in both limbs, and at the I-M joint of the pereiopod.

\section{Introduction}

The chordotonal organs of the brachyuran walking leg form one of the best described proprioceptive systems in the invertebrates (Finlayson, 1968). The nature of the unit responses from these receptors is well known (Bush, 1965a and b; Clarac, 1968 b; Hartman and Boettiger, 1967; Wiersma, 1959; Wiersma and Boettiger, 1959), and it has been 
demonstrated that the input from some of these leg joint receptors can exert a direct influence on the motor output to the leg muscles (Bush, $1962,1963,1965 \mathrm{c}$; Evoy and Cohen, 1969) but the significance of these receptors in the control of limb movements has yet to be properly described.

Our knowledge of crustacean limb joint receptors is, with few exceptions, limited to the brachyuran walking leg. The series of receptors for three peripheral joints in the antennule is described by Wyse and Maynard (1965) in the macruran Panulirus argus and the two proximal joints by Sandeman (1963) in the Stomatopod Squilla mantis, but it is difficult to draw comparisons between this head appendage and the thoracic walking leg.

In this paper we provide data on the proprioceptors of two macruran thoracic limbs, the 2 nd pereiopod (1st walking leg) and the 3 rd maxilliped of Homarus gammarus (L.) (=Homarus vulgaris M. Ed.). The chordotonal receptors present at all joints between the basipodite and dactylopodite are described. The complex receptor system of the thorax-coxopoditebasipodite region is noted, but not described here in detail and the receptors of the basi-ischio-meropodite region of the macruran walking: leg are fully described by Clarac and Masson (1969). This paper is intended to facilitate comparison of the macruran walking leg with the macruran 3rd maxilliped and the brachyuran walking leg. Comparison of the macruran 3rd maxilliped and 2nd pereiopod is interesting as these two thoracic limbs are similar in the early swimming larva (see Herrick, 1895), but in the adult they become specialised in different ways for different functions.

The 3rd maxilliped of the macruran decapods is morphologically similar to the generalised malacostracan limb (see Schmidt, 1915) with some differences in the relative proportions of the limb segments. It may thus be argued that the $3 \mathrm{rd}$ maxilliped in macrurans is less specialised and more primitive in form than the pereiopods. The relatively unspecialised structure of this limb is indicated by the uniform mobility available at each of its joints with the exception of the basipodite-ischiopodite joint which has fused.

The thoracic appendages anterior to the 3rd maxilliped are modified to a greater or lesser extent for feeding whilst those situated caudally are mainly locomotory. In Homarus gammarus the 3rd maxilliped is utilised for holding larger particles of food, the smaller particles being passed directly by the 2 nd pereiopods to the more anterior mouth parts. The food is grasped between the toothed edges of the ischium and the more distal segments are reflected to retain the food. They are also utilised in antennular cleaning, the antennae being pulled between the 
extended maxillipeds and in digging when they act in conjunction with the 2nd and 3rd pereiopods. In the latter action, the 3rd maxillipeds are held apart and extended with the pereiopods brought up underneath to add support and form a scoop. By this method the lobster can perform considerable excavations in search of food (see Herrick, 1895). The functions of the 3rd maxilliped do not involve precise or manipulative actions.

The 2nd pereiopod is mainly concerned with support and locomotion and the lobster can progress equally well in any direction, unlike the crabs which are more proficient in lateral movement. The pereiopods of the lobster are also involved in gathering food particles, which they pass forward and in eleaning of the cephalothorax and abdomen. The pereiopods are capable of actions requiring flexibility and precision such as cleaning of the upper carapace and rostral area. The pereiopods have retained a remarkable degree of flexibility despite the comparative rigidity required for walking.

The leg of Carcinus on the other hand, has become specialised for lateral rapid movement, and is less flexible than the macruran pereiopod, having lost the facility to rotate at the $\mathrm{CP}$ joint. It is not chelate. Hence the typical brachyuran pereiopod is less effective in manipulative tasks such as cleaning and food handling.

As the form of the receptors present at any joint is dependent on the nature of the joint we have included a description of the structure and degrees of freedom of the joints. Descriptions of the musculature have also been included as large differences exist between the 3rd maxilliped and pereiopod, and because the lack of information on the pereiopod of Homarus gammarus (L.) has led to omissions by other authors.

\section{Materials and Methods}

Homarus gammarus (L.) was the species used in the majority of the investigations and unless stated otherwise all results are for this species. They were obtained locally and kept in tanks of circulating sea water until required. Comparative studies were carried out on Nephrops norvegicus also obtained on the Fife coast, on Panulirus argus at the Bermuda Biological Station, St. George's West, Bermuda, and on Astacus leptodactylus in France.

The musculature was observed in appendages first fixed in Bouin's fixative, and then dissected in $70 \%$ alcohol. The innervation of receptor systems was studied using methylene blue staining of fresh material in one of the following three ways, based on a standard $1 \%$ solution of stain made up in distilled water.

1. A suspected receptor region was partially exposed by dissection and the preparation then left overnight at about $5^{\circ} \mathrm{C}$ in a refrigerator. The staining solution, a very pale blue colour, was obtained by dilution with sea water. Further dissection and periods of low temperature staining permitted detailed examination of the receptor.

2. The receptor system was dissected and left to stain in a concentrated solution of methylene blue in sea water. In this method it was essential that the 
appropriate area should lie close to the surface of the staining solution. The preparation was examined frequently for short periods in clean sea water. This rapid method gave intense staining of the nerve cell somata.

3. The injection and inspection methods of Alexandrowicz and Whitear (1957) provided the third method.

After staining, all preparations were fixed in saturated ammonium molybdate for $10-24$ hours at $5^{\circ} \mathrm{C}$, washed in distilled water, dehydrated in absolute alcohol, and then cleared in xylene before being mounted in gum dammar or polystyrene.

Conventional wire electrode recording techniques were used for demonstration of nervous activity in selected receptor organs. Movements of appropriate joints were made by a micromanipulator/potentiometer system (Shelton and Laverack, 1968).

\section{Results}

The joints of the limbs and the receptors present at these joints will be referred to by the initials of the names of the limb segments between which the joint occurs. For example, the joint between the carpopodite and the propodite is the C-P joint and the receptors present at this joint are $\mathrm{CP}_{1}$ and $\mathrm{CP}_{2}$.

\section{General External Features}

a) The Walking Leg. The Homarus walking leg as typified by the second pereiopod (Figs. 1, 2 and 4 ) is different in several ways from the equivalent limb in the brachyuran, Carcinus (see Whitear 1962, Fig. 1).

The most striking difference lies in the chelate nature of the P-D joint. In this it differs from the fourth and fifth pereiopods of Homarus itself as well as from the brachyuran walking leg. In both groups the first pereiopod, of course, forms the great claw.

With the exception of the most proximal segments, the leg of Homarus is ovoid in cross section and of similar width throughout its length. The legs of Carcinus are flattened laterally and are broader at the base, tapering towards the distal extremity. In Carcinus the basipodite and ischiopodite have fused but in Homarus these two segments remain separate. The ischiopodite is of greater length relative to the other leg segments in Homarus (where it is $15-20 \%$ of the total leg length) than in Carcinus (where it is only $8-10 \%$ of the total length).

The joints of the second pereiopod of Homarus allow greater flexibility than occurs in the crab leg. The degrees of movement possible at the respective joints and the planes in which the movements occur are shown in Figs. $2 \mathrm{~B}$ and $4 \mathrm{~B}$. The degree of movement indicated is the maximum possible, not necessarily the movement achieved by the animal and the plane of movement is not always exactly in the plane of the paper. The greatest degrees of freedom in Homarus legs occur at the M-C and C-P joints which permit movement in the dorsal-ventral and 


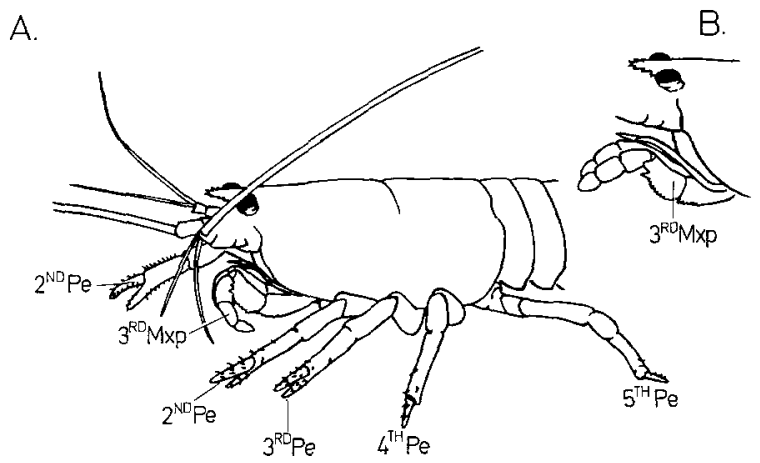

Fig. 1. A. An outline drawing traced from a photograph of Homarus gammarus (L.) in a normal resting stance. The lst pereiopods, chelae, have been removed by autotomy to allow the 3rd maxillipeds $(M x p)$ and other pereiopods $(P e)$ to be seen more readily. See text for descriptions of limb usage. B. Demonstrates the 3rd maxillipeds held in the extended position

anterior-posterior plane respectively. As described later, the C-P joint is so constructed that the propodite is able to rotate about the longitudinal limb axis. Rotation is not possible at the C-P joint of the chela of Homarus or at any joint of any limb of Carcinus. The high degree of freedom at the M-C joint is of value when the animal walks sideways as this joint is responsible for most of the movement. The C-P joint, however, moves only slightly when the animal walks regardless of the direction of movement. Walking in an anterior or posterior direction is achieved by movement at the more proximal joints. Although the basipodite and ischiopodite are not fused as they are in the 3rd maxilliped, movement at the joint is restricted.

b) The Third Maxilliped. The disposition of the 3rd maxilliped of Homarus is completely different from that of the walking leg (Fig. I) since it usually lies along the body axis rather than at a right angle to it. Thus the posterior face of the walking leg is equivalent to the external or lateral wall of the 3rd maxilliped. The 3rd maxilliped does not support any of the body weight and when not in motion it adopts one of two characteristic attitudes. The limb may be extended, the distal portion gently curving downwards and inwards so that the tips of the dactylopodites are closely apposed (Fig. 1B) or the distal three segments may be reflected back under the proximal segments by complete flexion of the M-C joint (Fig. 1 A).

The distal segments (carpopodite, propodite and dactylopodite) of the 3rd maxilliped are ovoid and the ischiopodite is triangular in cross section. The basipodite and ischiopodite are fused to form the longest 

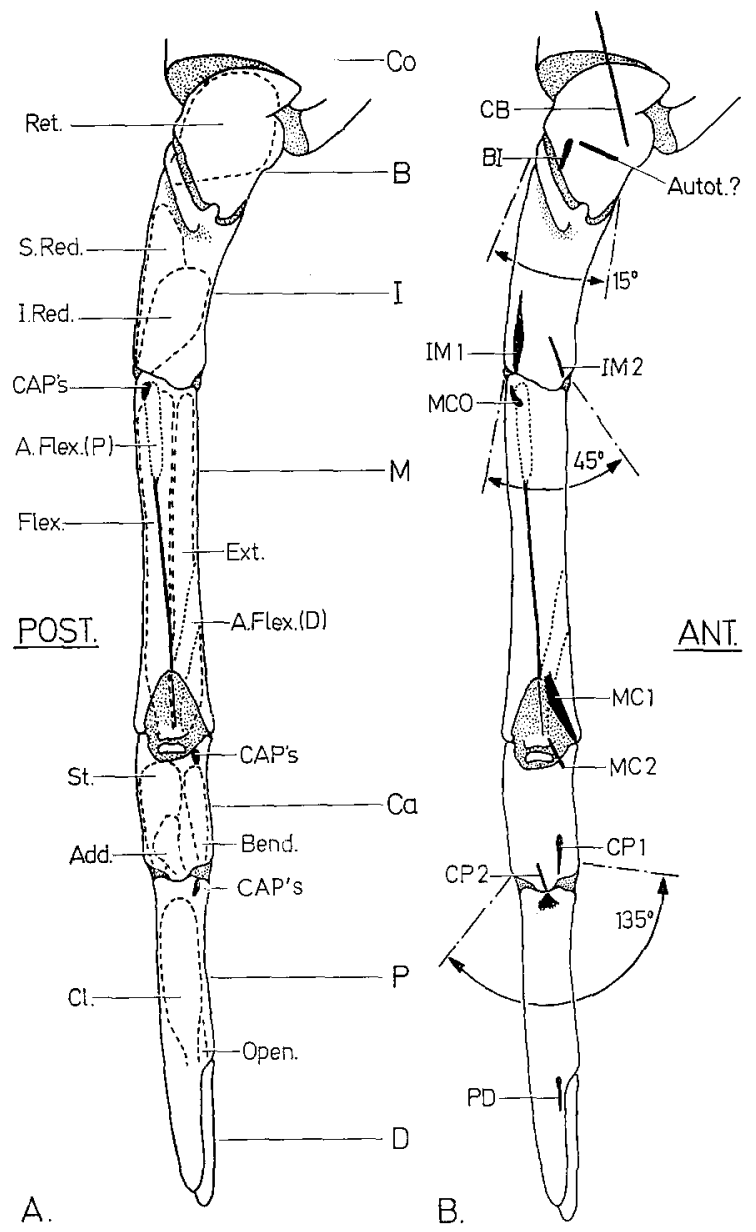

Fig. $2 \mathrm{~A}$ and B. Ventral views of a left walking leg of H.gammarus with the relevant parts of the internal anatomy shown in transparency. A. To show the musculature and the position of the externally located cuticular articulated peg sensilla $\left(C A P^{\prime} s\right)$. B. To show the position of the internal chordotonal organs and the extent of movement possible at each of the joints. Segments: coxopodite $(C o)$, basipodite $(B)$, ischiopodite $(I)$, meropodite $(M)$, carpopodite $(C a)$, propodite $(P)$, dactylopodite $(D)$. Muscles: retractor (Ret.), superior reductor (S. Red.), inferior reductor $(I . R e d$.$) , flexor (F l e x$.$) , extensor (E x t$.$) , accessory flexor proximal head$ (A. Flex. (P.)) and distal head (A. Flex. $(D))$, stretcher (St.), bender (Bend.), additional muscle (Add.), closer $(C l$.$) , opener (Open.). Receptors: The receptors are$ named by the initials of the limb segments which constitute the joint at which they are situated. An exception to this rule is the myochordotonal organ (MOO) which responds to movement of the $M-C$ joint although the sensory cells are situated close to the $I-M$ joint. Autot. indicates the position of the possible autotomy receptor in the basipodite. For the orientation shown, posterior (POST.) and anterior ( $A N T$.) relate to the position of the limb in its normal attitude (see Fig. 1) 


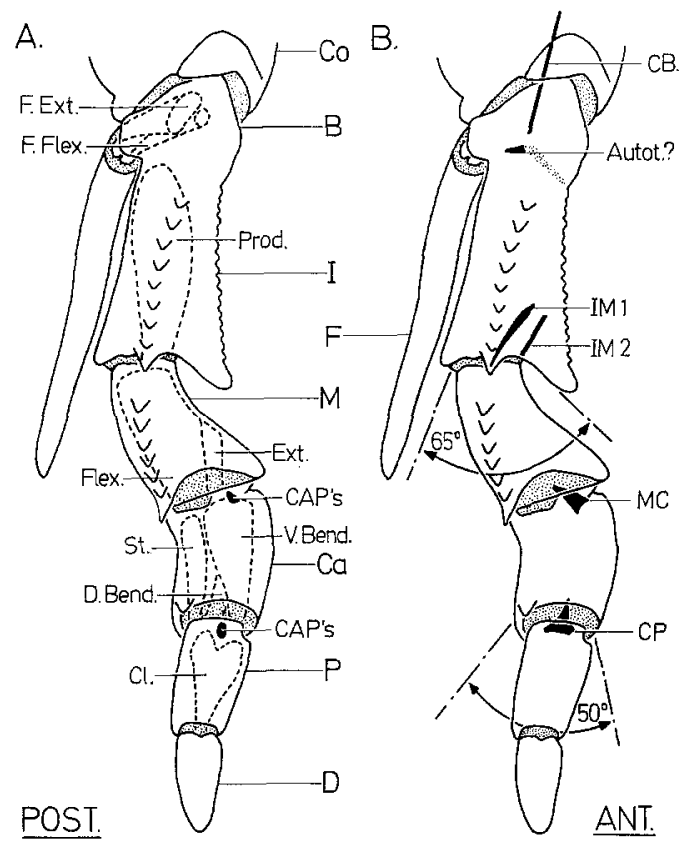

Fig. 3A and B. Ventral view of the left 3rd maxilliped of H.gammarus. As explained in the text, it would be more appropriate to use the terms lateral and medial to describe the orientation of this limb rather than posterior and anterior, but use of the latter terms facilitates comparison with the pereiopods. The lettering is as in Fig. 3 except for the following: Segments: flagellum $(F)$. Muscles: flagellum extensor $(F . E x t$.), flagellum flexor $(F . F l e x$.$) , productor (Prod.), ventral$ bender ( $V$. Bend.), dorsal bender (D. Bend.)

segment (35\% of total limb length) whereas the meropodite is the largest in the walking legs ( $30 \%$ of the total limb length). There is also a noticeable diminution in relative size of the distal segments of the limb by comparison with the walking leg. The P-D joint of the $3 \mathrm{rd}$ maxilliped is not chelate.

There are different capacities for movement at each of the joints with respect to the pereiopod (see Figs. $3 \mathrm{~B}$ and $5 \mathrm{~B}$ ). In particular the C-P joint differs from the walking leg in that it does not have the ability to rotate but its movement is not restricted to a single plane. The degrees of freedom at the different joints do not vary as much as in the 2nd pereiopod and all joints are capable of being moved through at least $50^{\circ}$. The 3rd maxilliped thus maintains a considerable degree of flexibility throughout its length.

c) Cuticular Articulated Pegs. Distal to the M-C and C-P joints of the walking legs and 3rd maxilliped groups of sensilla are readily observed 


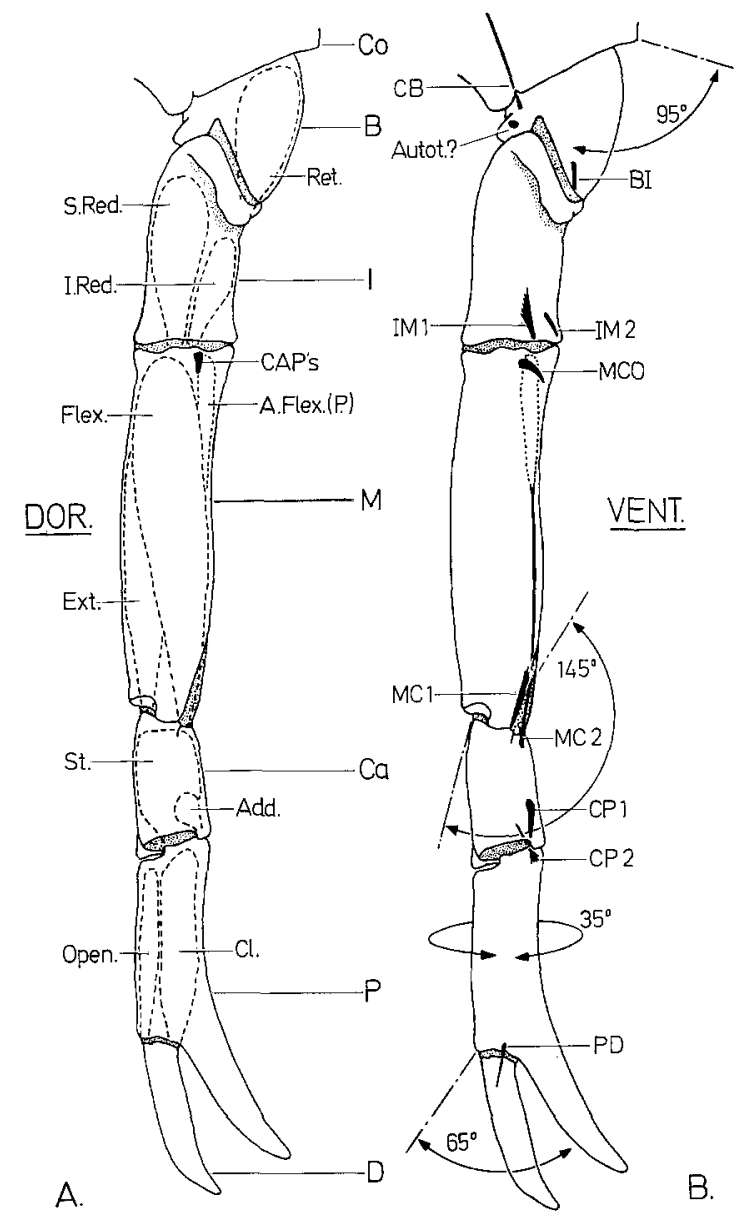

Fig. 4A and B. Posterior views of the left walking legs of H. gammarus with the relevant parts of their internal anatomy shown in transparency. A. To show the musculature and the position of the externally located cuticular peg sensilla (CAP's). $B$. To show the position of the internal chordotonal organs and the extent of movement possible at each of the joints. The lettering is the same as for Fig. 2

on the surface of the limb. These sensilla lie close to the endings of internally placed chordotonal organs $\left(\mathrm{MC}_{2}\right.$ and $\mathrm{CP}_{2}$ of the walking leg, $\mathrm{MC}$ and $\mathrm{CP}$ of the 3rd maxilliped). A further group lies at the I-M joint of the walking leg (Myochordotonal organ). These sensilla which were previously referred to as "slit sensilla" and described as "pits" (Wiersma, 1959) we have renamed, Cuticular Articulated Pegs (CAP's). Our reasons for changing the name are given in the discussion. 


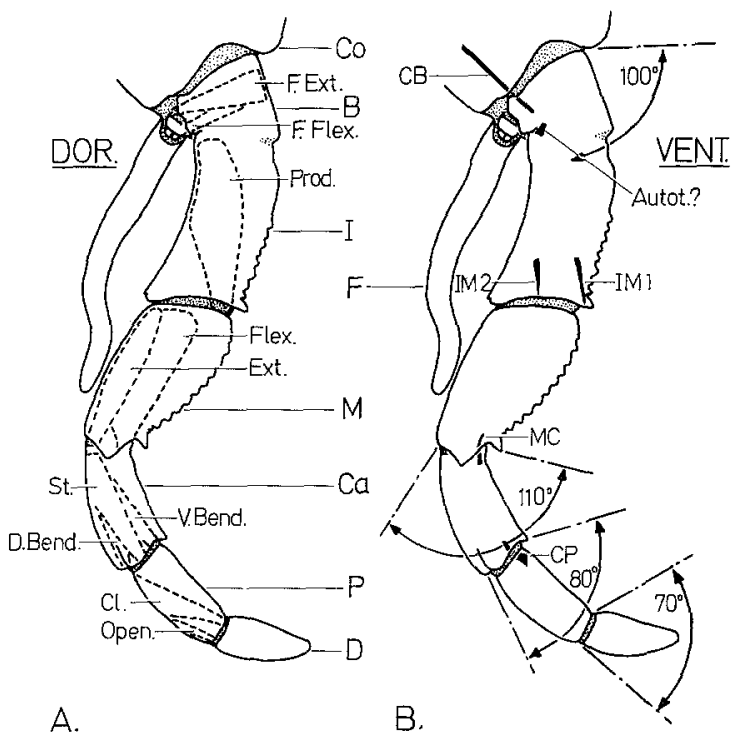

Fig. 5. Posterior views of the left 3rd maxilliped of H.gammarus. The lettering is the same as for Figs. 2 and 3

The groups of CAP's are situated distal to the joint and lie in such a position as to be touched by the articular membrane during movement of the joint. At the I-M joint, only half of the group is covered by the membrane even at full reduction. At the M-C joint of the walking leg the articular membrane makes contact with the CAP's when the joint is flexed through $90^{\circ}$ and this is the normal position of this joint when the animal is at rest (Fig. 1).

The CAP's are small spines situated in pits at the end of canals through the cuticle (Fig. 6) which "contain the end part of the scolopidia in which terminate the processes of the sensory cells of the respective receptors" (Alexandrowicz, 1969). The spines are of differing lengths in different species, they are longest in Nephrops norvegicus (relative to the animal's size), shorter in Homarus and exist only as small knobs in Panulirus argus. The number of sensilla in a group varies between 45 and 85 in Homarus and may vary at the same joint in different animals. The CAP's are closely grouped together and form rows.

The CAP's are innervated by bipolar sensory cells, the axons of which lie in the same nerve bundle as those of the proprioceptor cells alongside which they are situated. The cells of the CAP's are usually situated close to the hypodermis and the number observed to stain is only a fraction of the total number of sensilla. This probably represents capricious staining and we believe that each sensillum is innervated by at least one sense cell (but see Laverack and Ardill 1965 on aesthetase hair innervation). 

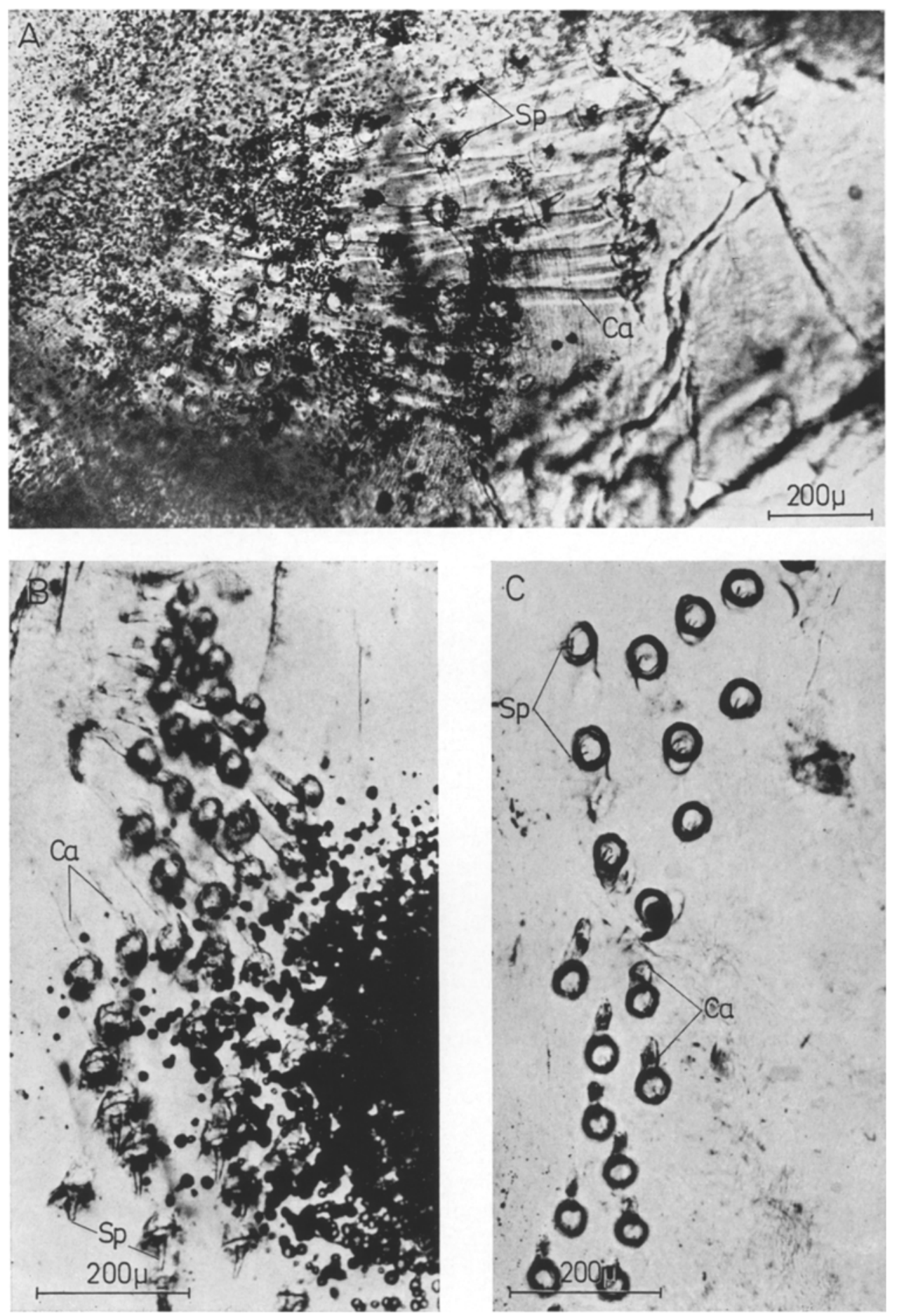

Fig. $6 \mathrm{~A}-\mathrm{C}$ 


\section{Joint Anatomy}

Figs. 2 to 5 summarize the anatomy of the walking leg and 3rd maxilliped in Homarus. The chordotonal organs and the CAP's lie close to one another and are illustrated on separate diagrams so that their positions may be clearly seen. The muscles of the macruran limbs were named by Schmidt (1915) but where possible we have followed the nomenclature of Bush, Whitear and Wiersma in recent papers on the decapod walking leg for the musculature of the pereiopods and the 3rd maxilliped. The musculature of the walking legs of Carcinus and Homarus and of the 3rd maxilliped of Homarus are compared in Table 1. Tables 2 to 4 summarize the properties of the chordotonal receptors present in these limbs.

Table 1. Summary of muscles in appendages. The abbreviations: $D=$ dorsal, $V=$ ventral, $A=$ anterior and $P=$ posterior, indicate the distal attachment of the muscle and the direction in which they move the segment on which they insert (relative to the other segments)

\begin{tabular}{|c|c|c|c|c|c|}
\hline \multirow[t]{2}{*}{ Joint } & \multirow{2}{*}{$\begin{array}{l}\text { Segment } \\
\text { moved }\end{array}$} & \multirow{2}{*}{$\begin{array}{l}\text { Proximal } \\
\text { attachment } \\
\text { of muscles }\end{array}$} & \multicolumn{3}{|l|}{ Muscles of } \\
\hline & & & $\begin{array}{l}\text { Carcinus } \\
\text { walking leg }\end{array}$ & $\begin{array}{l}\text { Homarus } \\
\text { walking leg }\end{array}$ & $\begin{array}{l}\text { Homarus } \\
\text { 3rd. Max. }\end{array}$ \\
\hline $\mathrm{B}-\mathrm{F}^{\mathrm{T}}$ & Flagellum & Basium & Not present & Not present & $\begin{array}{l}\text { Extensor } \\
\text { Flexor }\end{array}$ \\
\hline B-I & Ischium & Basium & Fused & Retractor $\mathrm{V}$ & Fused \\
\hline I-M & Merus & Ischium & Reductor $\mathbf{P}$ & $\begin{array}{l}\text { Superior } \\
\text { reductor } \mathbf{P} \\
\text { Inferior } \\
\text { reductor P }\end{array}$ & $\begin{array}{l}\text { Productor } \\
\text { V-A }\end{array}$ \\
\hline M-C & Carpus & Merus & $\begin{array}{l}\text { Extensor D } \\
\text { Flexor V } \\
\text { Acc. flexor V }\end{array}$ & $\begin{array}{l}\text { Extensor D } \\
\text { Flexor V } \\
\text { Acc. flexor V }\end{array}$ & $\begin{array}{l}\text { Extensor D } \\
\text { Flexor V }\end{array}$ \\
\hline C-P & Propus & Carpus & $\begin{array}{l}\text { Stretcher } \\
\text { (Reductor) P } \\
\text { Bender } \\
\text { (Productor) A }\end{array}$ & $\begin{array}{l}\text { Stretcher P } \\
\text { Bender A } \\
\text { Additional }\end{array}$ & $\begin{array}{l}\text { Stretcher P } \\
\text { Ventral } \\
\text { bender V-A } \\
\text { Dorsal } \\
\text { bender V-D }\end{array}$ \\
\hline P-D & Dactyl & Propus & $\begin{array}{l}\text { Opener D } \\
\text { Closer V }\end{array}$ & $\begin{array}{l}\text { Opener D } \\
\text { Closer V }\end{array}$ & $\begin{array}{l}\text { Opener D } \\
\text { Closer V }\end{array}$ \\
\hline
\end{tabular}

Fig. 6. Photomicrographs of unstained but cleared CAP sensilla from some representative macruran species. The structure of these sensilla is similar at the different limb joints at which they occur on the same animal. The photographs show the canals $(C a)$ through the cuticle to the spines $(S p)$ which are situated on a flexible membrane. A. Nephrops norvegicus. B. Homarus gammarus. C. Panulirus argus 
Table 2. Summary of receptors in Carcinus walking legs (information extracted from Bush, Clarac and Alexandrowicz). Compare this with Tables 3 and 4. Aff. $=$ afferent, Prox. $=$ proximal, resp. $=$ respond

\begin{tabular}{|c|c|c|c|c|c|}
\hline \multirow[t]{2}{*}{ Receptor } & \multirow{2}{*}{$\begin{array}{l}\text { Prox. end on } \\
\text { apodeme of }\end{array}$} & \multirow{2}{*}{$\begin{array}{l}\text { Joint } \\
\text { movement } \\
\text { stretching } \\
\text { receptor }\end{array}$} & \multirow{2}{*}{$\begin{array}{l}\text { Distal } \\
\text { end } \\
\text { across } \\
\text { joint }\end{array}$} & \multicolumn{2}{|c|}{ Aff. fibres resp. to } \\
\hline & & & & a) Stretch & b) Release \\
\hline $\mathrm{CB}$ & Not & Extension & Yes & Yes & Yes \\
\hline $\mathrm{IM}(\equiv \mathrm{IM} 1)$ & Reductor & Reduction & No & No & Yes \\
\hline $\mathrm{MC} 1$ & Accessory flexor & Flexion & No & Yes & Yes \\
\hline $\mathrm{MC} 2$ & Flexor & Flexion & Yes & No (?) & Yes \\
\hline CP1 & Bender (Productor) & Bending & No & Yes & Yes \\
\hline $\mathrm{CP} 2$ & Stretcher (Reductor) & Stretching & Yes & No (?) & Yes \\
\hline $\mathrm{PD}$ & Closer & Closing & Yes & Yes & Yes \\
\hline
\end{tabular}

Table 3. Summary of receptors in Homarus walking leg. Results from the present investigation. Abbrevialions as for Table 2

\begin{tabular}{|c|c|c|c|c|c|}
\hline \multirow{2}{*}{$\begin{array}{l}\text { Re- } \\
\text { ceptor }\end{array}$} & \multirow{2}{*}{$\begin{array}{l}\text { Prox. end on } \\
\text { apodeme of }\end{array}$} & \multirow{2}{*}{$\begin{array}{l}\text { Joint } \\
\text { movement } \\
\text { stretching } \\
\text { receptor }\end{array}$} & \multirow{2}{*}{$\begin{array}{l}\text { Distal } \\
\text { end } \\
\text { over } \\
\text { joint }\end{array}$} & \multicolumn{2}{|c|}{ Aff. fibres resp. to } \\
\hline & & & & a) Streteh & b) Releasea \\
\hline $\mathrm{CB}$ & Not & & Yes & & \\
\hline $\begin{array}{l}\text { BI } \\
\text { IM } 1\end{array}$ & $\begin{array}{l}\text { Retractor } \\
\text { Reductor }\end{array}$ & $\begin{array}{l}\text { Retraction } \\
\text { Reduction }\end{array}$ & $\begin{array}{l}\text { No } \\
\text { No }\end{array}$ & $\begin{array}{l}\text { No } \\
\text { No }\end{array}$ & $\begin{array}{l}\text { Yes } \\
\text { Yes }\end{array}$ \\
\hline IM2 & Reductor & $\begin{array}{l}\text { Reduction } \\
\text { and } \\
\text { production }\end{array}$ & No & Yes & No \\
\hline $\begin{array}{l}\mathrm{MC} 1 \\
\mathrm{MC} 2\end{array}$ & $\begin{array}{l}\text { Accessory flexor } \\
\text { Flexor }\end{array}$ & $\begin{array}{l}\text { Flexion } \\
\text { Flexion }\end{array}$ & $\begin{array}{l}\text { No } \\
\text { Yes }\end{array}$ & $\begin{array}{l}\text { Yes } \\
\text { No }\end{array}$ & $\begin{array}{l}\text { Yes } \\
\text { Yes }\end{array}$ \\
\hline $\begin{array}{l}\text { CP } 1 \\
\text { CP2 }\end{array}$ & $\begin{array}{l}\text { Bender } \\
\text { Stretcher }\end{array}$ & $\begin{array}{l}\text { Bending } \\
\text { Stretching }\end{array}$ & $\begin{array}{l}\text { No } \\
\text { Yes }\end{array}$ & $\begin{array}{l}\text { Yes } \\
\text { No }\end{array}$ & $\begin{array}{l}\text { Yes } \\
\text { Yes }\end{array}$ \\
\hline PD & Closer & Closing & Yes & $?$ & $?$ \\
\hline
\end{tabular}

a Results are from Astacus leptodactylus.

\section{Thorax-Coxopodite Joint (T-C)}

a) Walking Leg Receptors. The anatomy of the receports of this joint has been described by Alexandrowicz and Whitear (1957) for Homarus vulgaris (Milne Edwards) (= Homarus gammarus L.) and some brachyurans, and by Alexandrowicz (1967) for Palinurus vulgaris. There are two types of receptor present at the T-C joint, a chordotonal receptor and a 
Table 4. Summary of receptors of the 3rd maxilliped of Homarus. Abbreviations as for Table 2

\begin{tabular}{|c|c|c|c|c|c|}
\hline \multirow[t]{2}{*}{ Receptor } & \multirow{2}{*}{$\begin{array}{l}\text { Prox, end on } \\
\text { apodeme of }\end{array}$} & \multirow{2}{*}{$\begin{array}{l}\text { Joint } \\
\text { movement } \\
\text { stretching } \\
\text { receptor }\end{array}$} & \multirow{2}{*}{$\begin{array}{l}\text { Distal } \\
\text { end } \\
\text { over } \\
\text { joint }\end{array}$} & \multicolumn{2}{|c|}{ Aff. fibres resp. to } \\
\hline & & & & a) Stretch & b) Release \\
\hline $\mathrm{CB}$ & Not & & Yes & $?$ & $?$ \\
\hline $\begin{array}{l}\text { IM1 } \\
\text { IM2 }\end{array}$ & $\begin{array}{l}\text { Productor } \\
\text { Productor }\end{array}$ & $\begin{array}{l}\text { Reduction } \\
\text { Production }\end{array}$ & $\begin{array}{l}\mathrm{Yes}^{\mathrm{a}} \\
\text { No }\end{array}$ & No & Yes \\
\hline $\mathrm{MC}$ & Flexor & Flexion & Yes & Yes & Yes $^{b}$ \\
\hline $\mathrm{CP}$ & Ventral bender & $\mathrm{c}$ & Yes & Yes & No \\
\hline
\end{tabular}

a The main strand does not attach to the Meropodite but accessory strands do.

b The activity is greater on release than on stretching.

c As the movement of this joint is not confined to one plane, the movement is difficult to define in terms of joint movement, but contraction of the ventral bender is primarily responsible for stretching of the receptor.

muscle receptor. They lie parallel to each other and proximally both are attached to the same cuticular projection. There is also a pair of innervated elastic strands which insert proximally in the thorax and attach distally to the tendons of the levator and depressor muscles of the basipodite. Thus these receptors traverse the T-C and C-B joints and must be affected by movement of either joint.

b) 3rd Maxilliped Receptors. Despite numerous attempts we have been unable to demonstrate the presence of a chordotonal receptor and must assume that it is not present. The muscle receptor system is similar to that in the walking legs. The levator and depressor elastic strand receptors are present.

\section{Coxopodite-Basipodite Joint (C-B)}

a) Walking Leg Receptor. The receptor at this joint is described along with those of the thorax-coxopodite joint by Alexandrowicz and Whitear (1957). The strand of the chordotonal organ does not attach proximally to a peg as in Carcinus but divides into a number of strands which insert separately into the hypodermis.

b) 3rd Maxilliped Receptor. A chordotonal receptor is present and it is very similar in disposition to that in the walking leg. As the sensory nerve approaches the elastic strand it fans out to greater degree than in the walking leg. The elastic strand inserts proximally in the coxopodite close to the anterior hinge of the $\mathrm{T}$ - $\mathrm{C}$ joint and distally in the basipodite near to the receptor at the B-F joint. The bipolar cells of the receptor are scattered over most of its length, but the majority lie in that region where the nerve joins the strand. 


\section{Basipodite-Flagellum Joint (B-F)}

This joint is present only in the 3rd maxilliped as the pereiopods in the adult do not carry a flagellum. The movement at this joint is produced by a pair of antagonistic muscles, an extensor and a flexor, which insert onto the ventral wall of the basipodite. This differs from the brachyura which have only one muscle, an extensor, flexion being produced by the elasticity of the joint. The motor control of flagellar movement in the Brachyura and Anomura is described by Burrows and Willows (1969) but as yet no proprioceptors have been described. A sense organ is situated near the flagellar articulation (Fig. 7) but may not monitor movement of this joint (see section $4 \mathrm{~b}$ ).

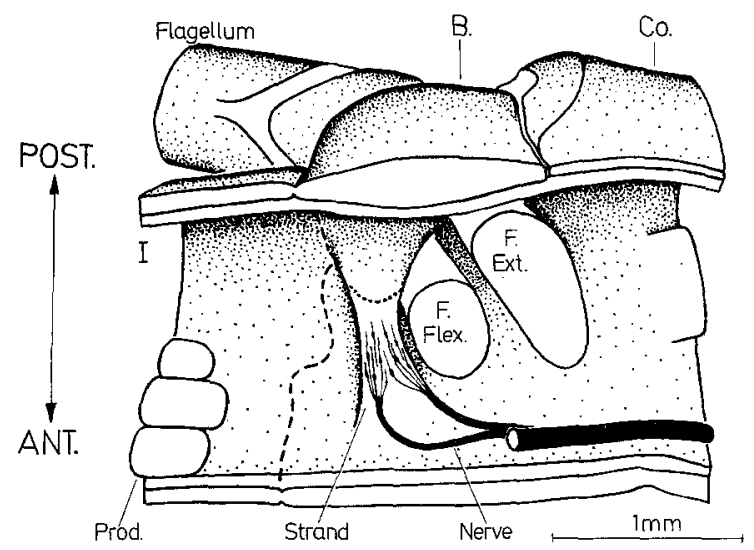

Fig. 7. A sense organ is present near to the articulation of the flagellum with the basipodite of the $3 \mathrm{rd}$ maxilliped. This receptor which lies close to the fusion line of the basipodite with the ischiopodite may be involved in the control of autotomy. The figure shows a ventral view of a portion of the left $3 \mathrm{rd}$ maxilliped of $H$. gammarus. The main leg nerve runs close by the receptor and has been removed in this diagram. This receptor is attached posteriorly to an internal cuticular projection (dotted line) and anteriorly to an area of soft cuticle. The broken line indicates the line of fusion. Basipodite $(B)$, coxopodite $(C o)$, ischopodite $(I)$, productor muscle (Prod.), flagellum flexor muscle (F.Flex.), flagellam extensor muscle (F. Ext.), posterior (POST.), anterior (ANT.)

\section{Basipodite-Ischiopodite Joint (B-I)}

The walking leg has a joint at the B-I junction. Movement is accomplished by a single muscle (retractor) that inserts posteriorly to produce movement in a lateral direction with respect to the body. An antagonistic muscle is absent and the counter movement is produced by elasticity and the disposition of body weight. The amount of movement possible at this joint is small. 


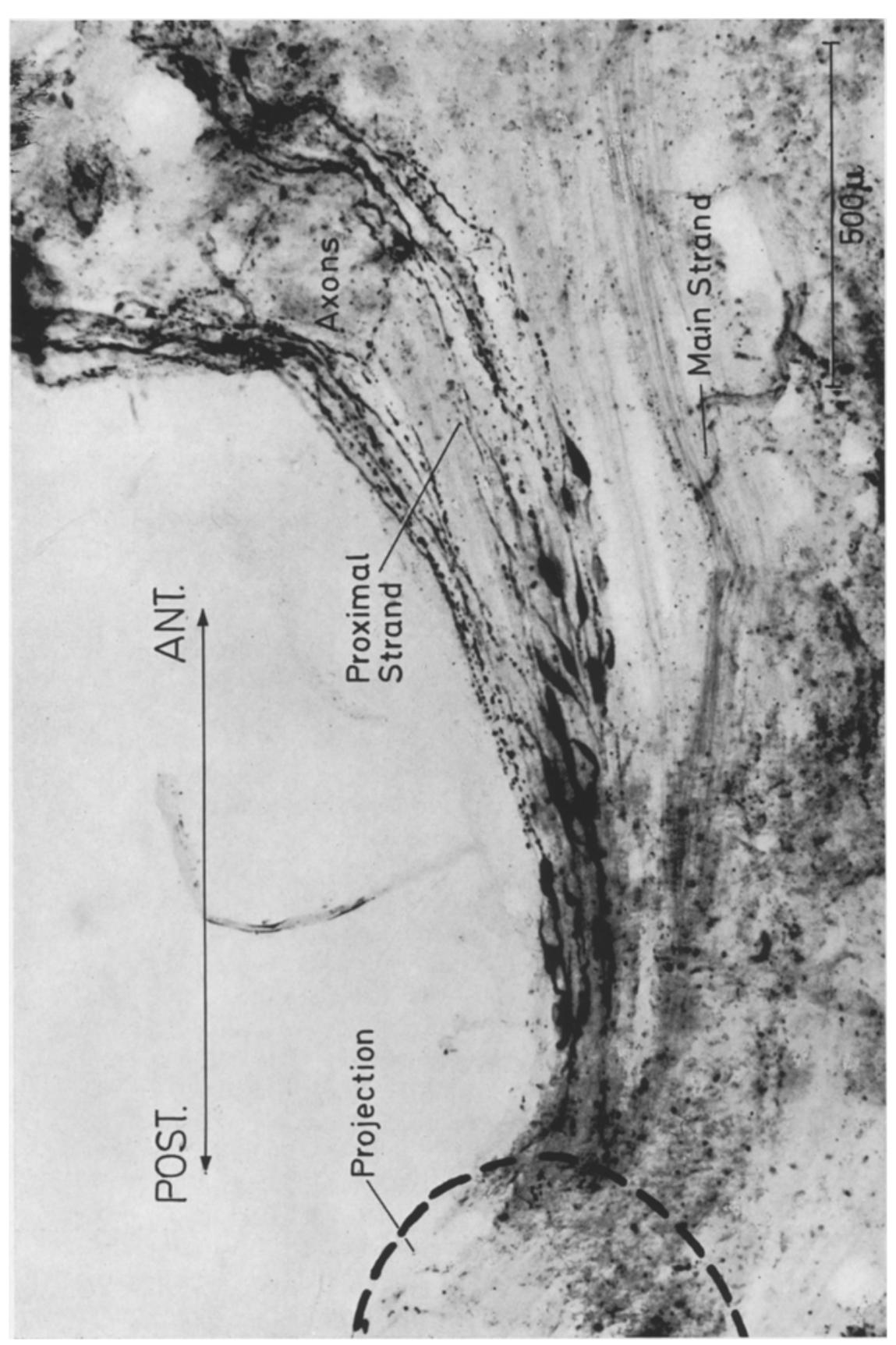

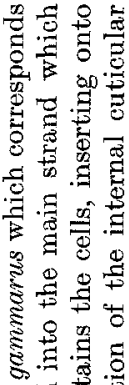

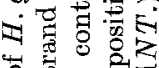

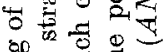

\&

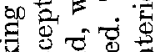

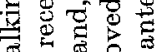

焉害要

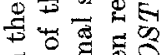

.

훙.

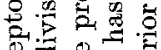

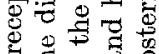

ง

का

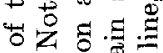

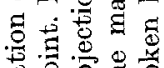

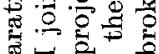

需

की

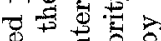

역.을

露品

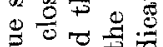

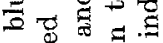

里

运证

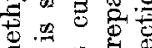

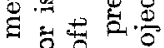

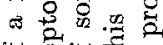

바웡

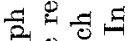

象焉造

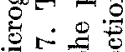

范

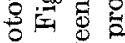

$\exists . \exists$

$\infty$ 远

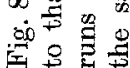


There is no comparable joint in the 3rd maxilliped as the two segments are fused to form a single entity.

a) Walking Leg Receptors. The anatomy of the chordotonal organ present at this joint is closely similar to that in Astacus leptodactylus as described by Clarac and Masson (1969).

Also present close to the B-I joint is a sense organ of unusual structure (Fig. 8) the function of which has not yet been determined physiologically. The sense organ is situated dorsally in the basipodite and lies in a plane parallel to the diameter of the limb (i.e. secantially). Thus the strand runs across the limb unlike the limb proprioceptors which lie approximately parallel to the Iongitudinal limb axis. The strand is divided anteriorly into two. The anterior insertion of the main strand is on a small area of soft cuticle whilst the proximal portion of the strand arises from the hypodermis. Both portions of the strand insert posteriorly on an internal cuticular projection. The strand does not cross a joint nor is it attached to a muscle. The nerve to the receptor arises from the main leg nerve close to the sense organ and joins the proximal strand close to its anterior insertion. Scattered through the mid region of the strand are 20-30 bipolar neurones the dendrites of which are directed towards the cuticular projection.

Preliminary observations have shown a corresponding receptor to be present in Palinurus vulgaris, Astacus leptodactylus, and in Carcinus maenas where it lies just proximal to the plane of autotomy.

b) 3rd Maxilliped Receptor. The chordotonal receptor associated with the B-I joint is absent in this limb in which the joint has fused.

Situated posteriorly between the flagellar insertion and the line of fusion between the basipodite and ischiopodite is a sense organ (Fig. 7) comparable to that described in the walking leg. The strand is not divided into two portions, but consists of a column of tissue with a core of stronger fibres. As with the walking leg, the strand is inserted posteriorly on an internal cuticular projection and anteriorly on a small distinct area of soft cuticle. The nerve trunk to the receptor does not arise directly from the main leg nerve but from a smaller branch which passes close by the anterior insertion of the strand. The receptor nerve invariably splits into two branches both of which innervate the strand. The neurones in the strand are smaller than those of the walking leg receptor and they are situated within the mid region of the strand.

\section{Ischiopodite-Meropodite Joint (I-M)}

The amount of movement which is possible at the I-M joint is similar in both limbs. The musculature, however, differs considerably.

In the pereiopod there are two reductor muscles which serve to pull the meropodite in an anterior-ventral direction. 


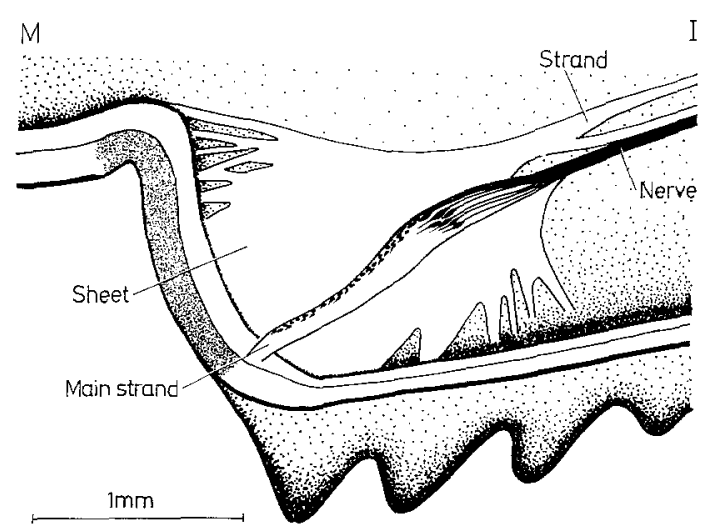

Fig. 9. A posterior view of the $\mathbf{I M}_{\mathbf{1}}$ receptor from the left $3 \mathrm{rd}$ maxilliped of $H$. gammarus. Note the grouping of the large cell bodies proximally and the linear arrangement of the smaller distal cells. Ischiopodite $(I)$, meropodite $(M)$

a) Walking Leg Receptors. Clarac and Masson (1969) have described the organization of $\mathrm{IM}_{1}$ in Astacus leplodactylus and the arrangement is the same in Homarus. The total number of sense cells in these receptors is about 60 by comparison with the brachyuran Carcinus where only 20-25 have been counted (Clarac, 1968a).

$\mathrm{IM}_{2}$ which is present in Homarus and Astacus appears to be analogous with $\mathrm{MCO}_{2}$ (myochordotonal organ) in the Palinura and Brachyura as it occupies the same position (Clarac and Masson, 1969).

b) 3rd Maxilliped Receptors. The $\mathbf{I M}_{1}$ receptor (Fig. 9) is located in the ventral corner of the ischiopodite. It consists of a sheet of connective tissue which spans the joint and is connected proximally to the productor muscle by a long thin strand. The anatomy suggests that the organ is capable of responding to either active muscle movement or to passive joint movement. The nerve to $\mathbf{I M}_{1}$ runs parallel to the thin strand and where it reaches the sheet joins a thick connective tissue strand (main strand) which lies across the sheet at an angle approximately normal to the direction in which the sheet is deformed by joint movement. The main strand of the organ is attached proximal to the joint. The cell bodies $(30-40)$ are all situated on the main strand proximal to the joint with the smallest cells most distally placed. They form a column of sensory cells running the whole length of the strand. The dendrites project distal to the cell bodies but their terminations are unknown.

$\mathbf{I M}_{2}$ (Fig. 10) lies in the anterior corner of the ischiopodite (i.e. that with the largest tooth). It is much smaller having only 10-15 stainable cells and consists of a long thin strand which runs from the 


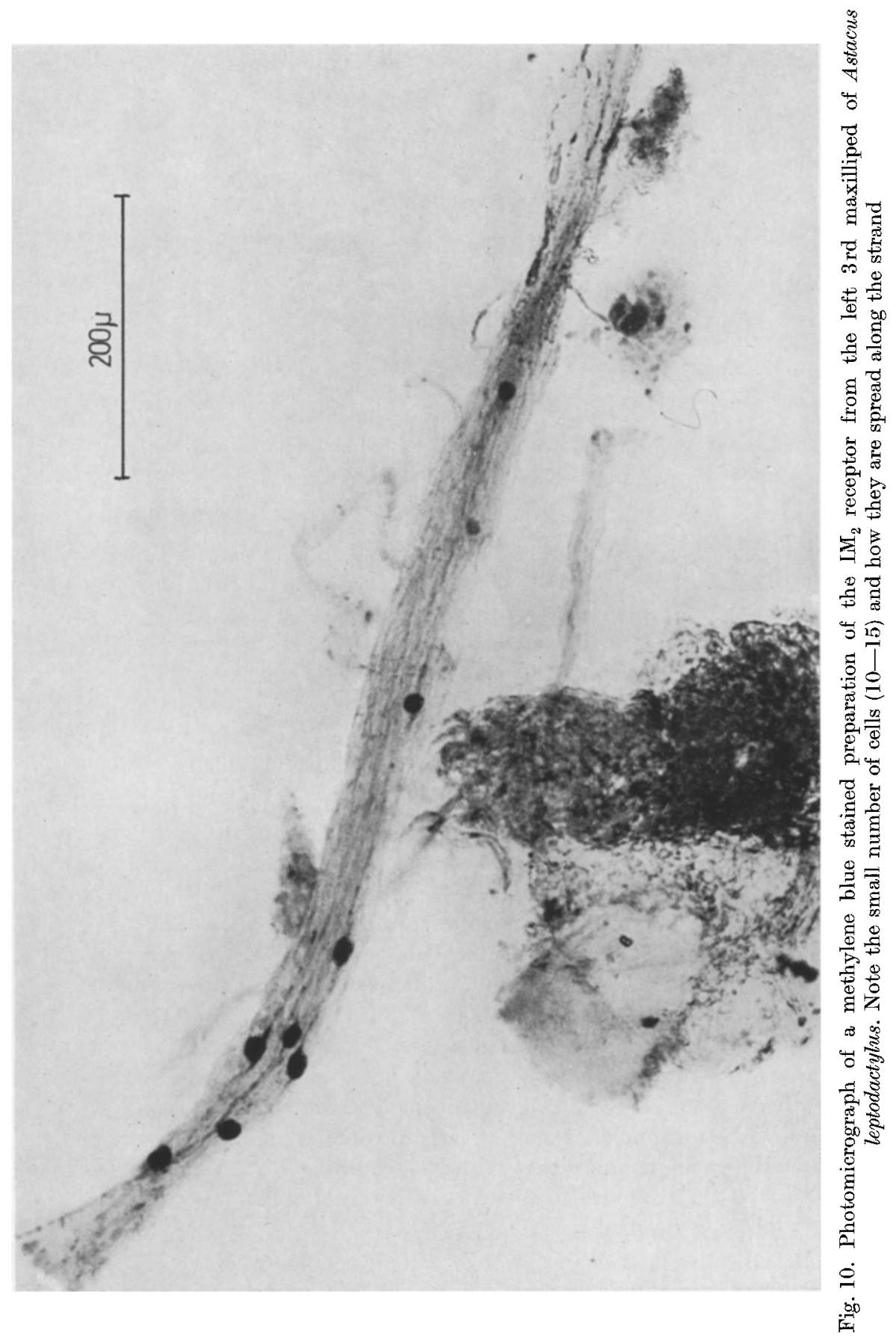


ventral surface of the productor muscle to attach distally in the hypodermis of the large tooth of the ischiopodite. The cells are fairly uniform in size and are scattered over most of the receptor strand.

\section{Meropodite-Carpopodite Joint (M-C)}

The pereiopod anatomy is particularly interesting at this joint because of the presence of the accessory flexor muscle, and the associated sensory apparatus $\left(\mathrm{MCO}_{1}\right.$, Barth organ). The pereiopod and 3rd maxilliped also have an extensor and a flexor muscle but the myochordotonal system is absent from the 3rd maxilliped.

The amount of movement possible at the M-C joint is greater in the walking leg where the joint is normally held flexed at an angle of approximately $90^{\circ}$. As mentioned previously this joint is very important in walking and is primarily responsible for lateral movements of the animal.

a) Walking Leg Receptors. $\mathrm{MC}_{1}$ is basically similar in disposition to that of Carcinus (Whitear, 1962) and consists of a sheet of connective tissue which is traversed by a strand. The proximal cells, however, are not spread out on the sheet but are confined to the strand and the cells are more evenly dispersed throughout the length of the strand. It also appears that the number of cells stained is slightly less than that of Carcinus.

$\mathrm{MC}_{2}$ (Fig. 11 A) shows marked differences to that of Carcinus and consists of a very thin strand of connective tissue which crosses the joint to insert into the hypodermis directly above the CAP organs in the carpopodite. The nerve to the proprioceptive organ travels alongside the apodeme of the accessory flexor muscle and is thickened to form a strand which runs from the junction of the apodemes of the accessory flexor and flexor muscles across the joint. Proximally there is very little connective tissue but distally the strand fans out and here its presence is more obvious. All the cells are situated at the most distal end of the strand and they are incompletely divided into two groups, an upper group which is embedded in the strand, and a lower group situated in the hypodermis external to the strand. The lower group, separated from the cells serving the chordotonal organ, is associated with the CAP organs.

b) 3rd Maxilliped Receptor. The MC receptor (Fig. 11 B) is attached proximally to the apodeme of the flexor muscle and distally spreads out to form a triangular sheet which covers the region of the carpopodite occupied by the CAP's. The receptor nerve runs alongside the flexor muscle to join the connective tissue close to its attachment on the apodeme. The cell bodies all lie distal to the joint and are divided into 

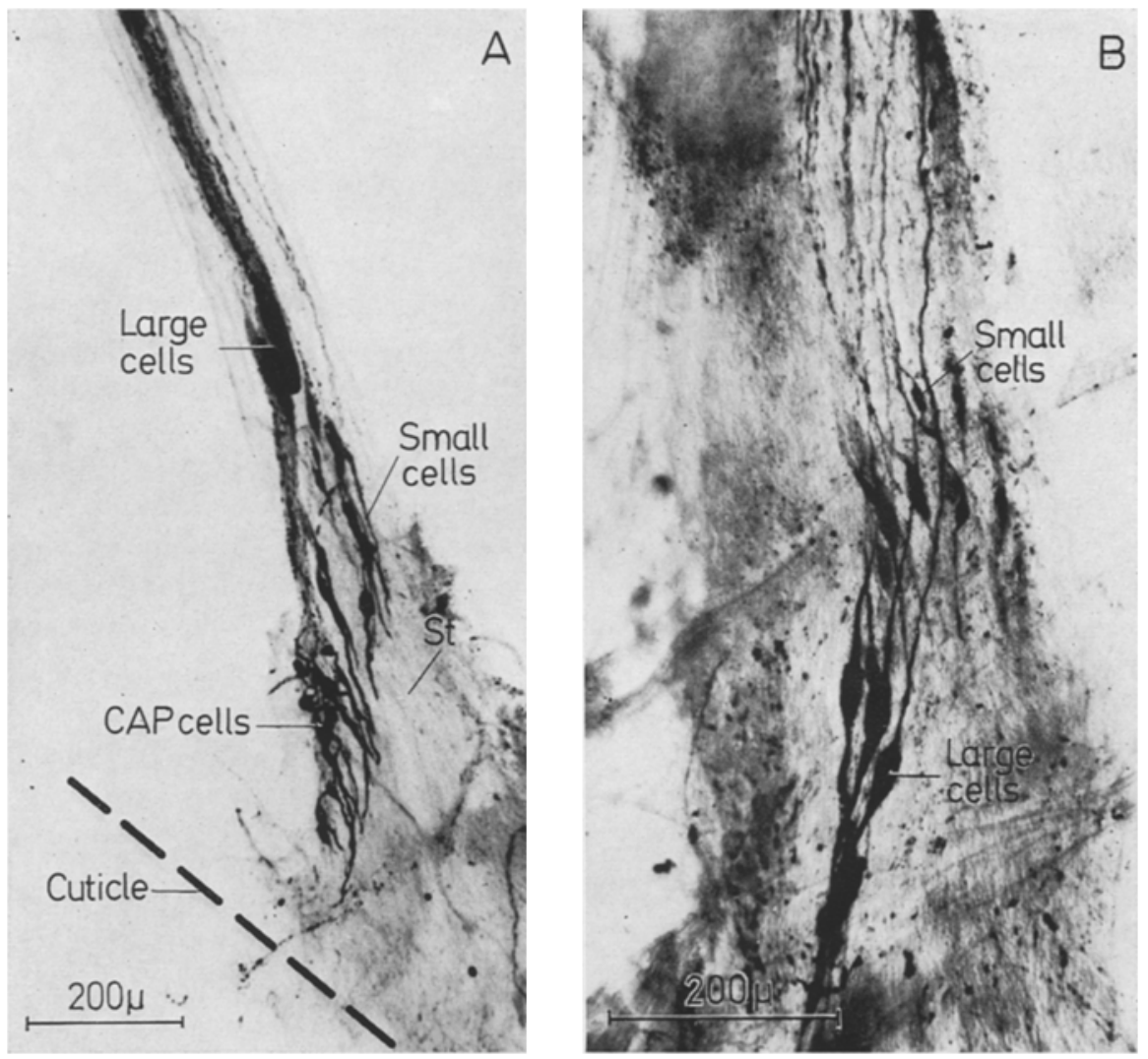

Fig. I1 A and B. Photomicrographs of methylene blue stained preparations of receptors from the M-C joint of $H$. gammarus limbs. A. The most distal portion of $\mathrm{MC}_{2}$ from the walking leg. The dotted line indicates the approximate position of the internal surface of the cuticle. B. The MC receptor from the 3rd maxilliped. This receptor shows a distinct division into two cellular groups, the larger of which are more distal than the smaller more proximal cells. The latter group appear to be associated with the CAP sensilla

two groups. One group lies medial to the sheet and these are the larger cells. The second group situated proximal to the first group lies in the hypodermis external to the sheet. It is possible that the latter group is associated with the CAP organs.

\section{Carpopodite-Propodite Joint (C-P)}

The anatomy of this joint is complex and the arrangement of the articulation, musculature and receptors make it perhaps the most interesting of the series. 
The walking legs and the 3rd maxilliped (but not the chelae) possess three muscles that control the movement of this joint as described by Wiersma and Ripley (1952) for the Natantia and Stomatopoda. The walking legs of Macrurans (Astacus fluviatilus, Palinurus vulgaris, Homarus gammarus and Nephrops norvegicus), Anomurans (Eupagurus bernhardus, Galathea strigosa, Dardanus asper) and a single brachyuran (Dormidiopsis dormia) have the facility to rotate the propodite about the longitudinal limb axis but with the exception of Homarus and Nephrops only two muscles, a stretcher and a bender are present. (Dardanus and Dromidiopsis are described by Wiersma and Ripley, 1954).

Articulation of the leg joints is usually accomplished by a single pair of symmetrically placed ball and socket joints. At the C-P joint of Homarus the mechanism is more complicated. Primary movement of the limb occurs in the antero-posterior plane (Fig. 2) and the hinge axis lies dorso-ventrally. The dorsal and ventral areas of contact between the coxopodite and the propodite have been enlarged and flattened to form very shallow ball and socket joints which tend to resist rotation of the propodite only when the limb supports the weight of the animal. These hinge pivots project internally towards the longitudinal axis of the limb until there is a gap of only $1-1.5 \mathrm{~mm}$ (in a joint with external diameter of $8-10 \mathrm{~mm}$ ) between them. The joint permits rotation through a maximum angle of $35^{\circ}$.

The major muscles that affect this joint are the stretcher and bender. The function of the third small muscle, previously undescribed, is not yet clear. The apodeme of this muscle is attached to the internal projection of the ventral portion of the hinge and its position indicates that it is likely to modify the action of the hinge rather than to rotate the distal portions of the leg. We were unable to rotate the limb by pulling the apodeme of the additional muscle either alone or concurrently with either of the other two muscles. We will not here propose a name for this muscle preferring to wait until functional studies make the situation clearer.

In the third maxilliped there are no distinct points of articulation and the joint is a very flexible one, with maximal movement possible in the dorso-ventral plane (Fig. 5), but some movement is allowed in all other directions. The three muscles that control the joint are so positioned that movement of the propodite in all directions is possible upon contraction of one or combinations of these muscles. Any single muscle opposes the action of the remaining two muscles. By virtue of their position we label two as benders (dorsal and ventral) and one a stretcher.

a) Walking Leg Receptors. $\mathrm{CP}_{1}$ (Fig. 12) is similar to that described for Carcinus (Whitear, 1962) in that the whole organ is located proximal 
W. Wales, F. Clarac, M. R. Dando and M. S. Laverack:

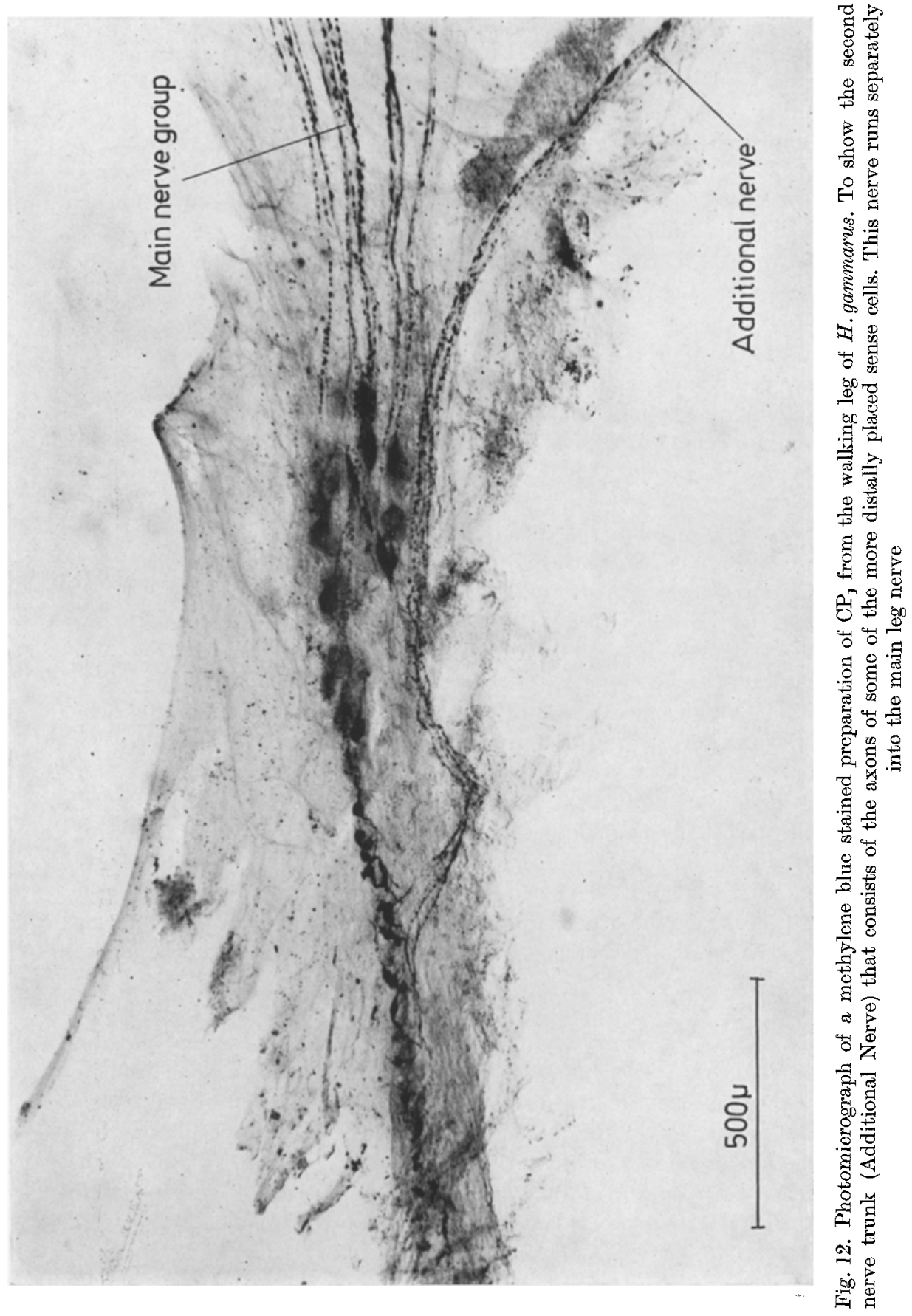



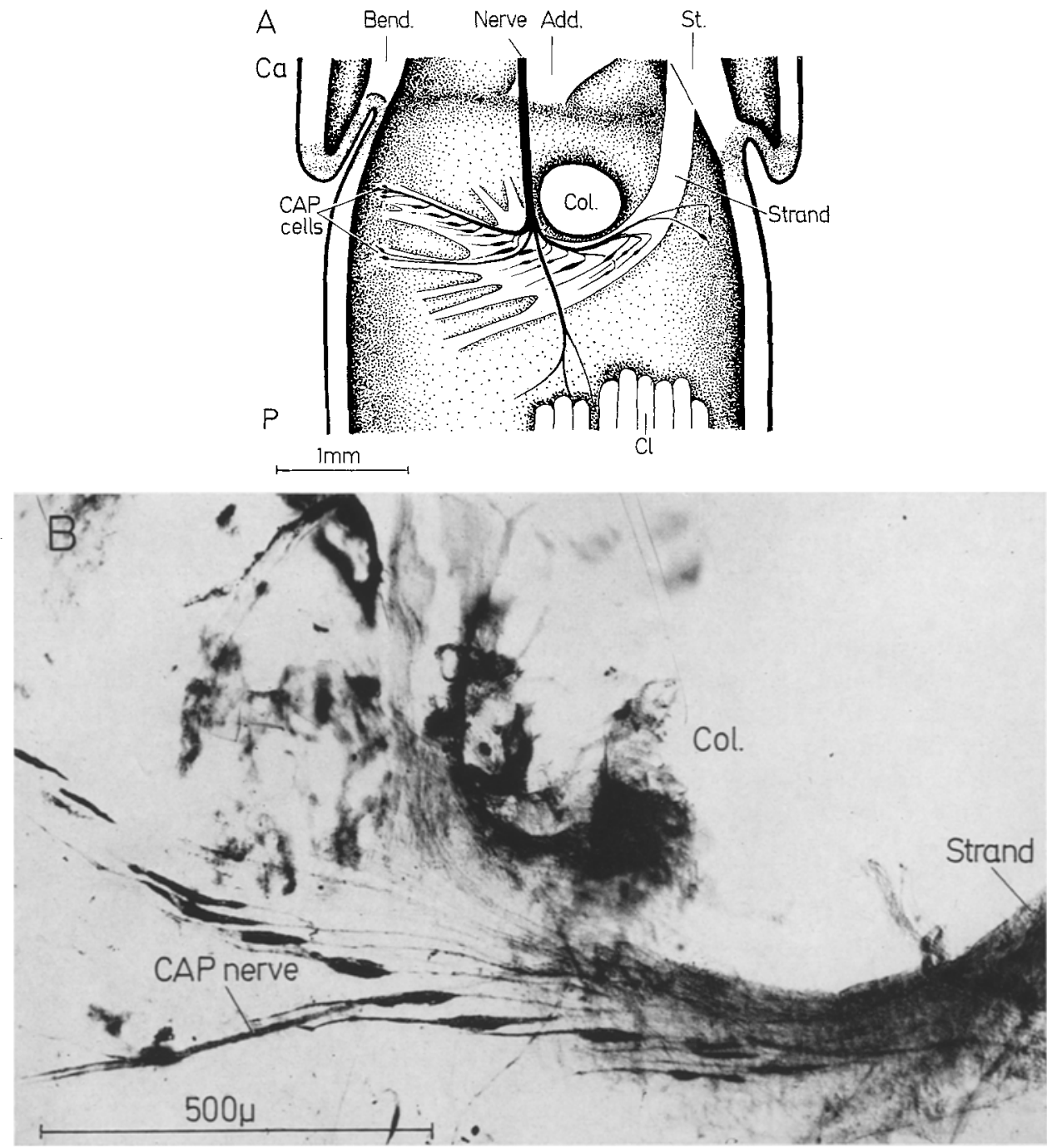

Fig. $13 \mathrm{~A}$ and $\mathrm{B}$. The C-P joint of the walking leg is one of the most interesting joints as both the structure of the joint and the associated receptors exhibit unusual features. A. A dorsal view of the $\mathrm{CP}_{2}$ receptor in the left 2 nd pereiopod of $H$. gammarus showing the manner in which it curves round the column of connective tissue to reflect some of the strand back towards the attachment of the additional muscle. Note that some of the axons of the receptor nerve do not innervate the receptor. B. Photomicrograph of a methylene blue stained preparation of $\mathrm{CP}_{2}$ showing the elongated bipolar cells and the curved shape of the receptor strand. Carpopodite $(C a)$, propodite $(P)$, apodeme of bender muscle (Bend.), apodeme of stretcher muscle $(S t$.$) , additional muscle (A d d$.$) , closer muscle (C l$.$) , column of$ connective tissue (Col.) 


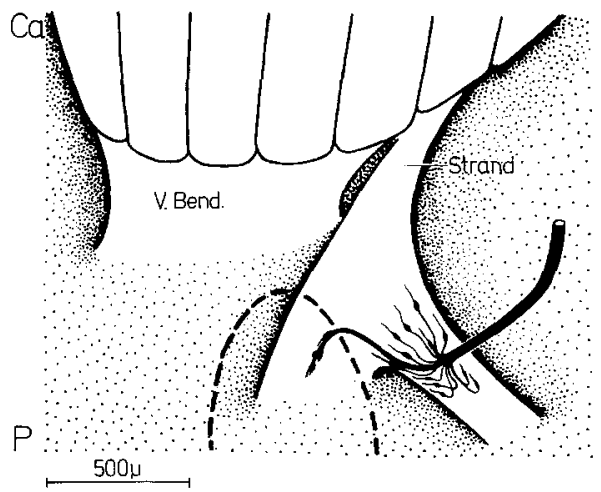

Fig. 14. Dorsal view of the CP receptor of the left 3rd maxilliped of $H$.gammarus. The cells are divided into two groups, one of which is situated internal to the CAP sensilla the position of which is shown by the broken line. The second are peculiar in the way they reflect back towards the carpopodite. Ventral bender muscle (V. Bend.), carpopodite $(C a)$, propodite $(P)$

to the joint. In Homarus, however, the organ is associated with two nerve trunks. The main leg nerve travels along the inner surface of the bender muscle and joins the connective tissue sheet proximal to the site of the receptor cell somata. A second nerve passes along the ventral hypodermis of the carpopodite from between the bender and stretcher muscle heads and innervates some cells which lie $1.5 \mathrm{~mm}$ or less from the distal attachment of the main strand.

The number of axons in this trunk is small, probably not more than 10 cells are innervated from this source, whilst the total number of cells in $\mathrm{CP}_{1}$ exceeds 80.

$\mathrm{CP}_{2}$ (Fig. 13) occupies a similar position to that of Carcinus, but has a different morphology. The two internal projections of the hinge are joined by a column of connective tissue (Fig. 13 A). The receptor strand of $\mathrm{CP}_{2}$ arises from the anterior surface of the stretcher muscle tendon and passes into the propodite posterior to the column. At this point the strand flattens out into a sheet which divides into branches and fans out, some branches being reflected back into the carpopodite. The nerve enters the propodite anterior to the column and curves round to meet the receptor sheet. At this point the nerve divides into several branches some of which pass across the receptor into the hypodermis.

The spindle shaped cell bodies (Fig. 13B) of the receptor are situated distal to the joint and the maximum number of cells observed was 27 . This number is greater than that quoted for Carcinus.

b) 3rd Maxilliped Receplor. As is the case with the M-C joint there is only a single receptor present at the C-P joint (Fig. 14) and from its 
position this is probably equivalent to $\mathrm{CP}_{2}$ of the walking leg. The connective tissue which is attached proximally to the ventral bender muscle, spreads out as it crosses the joint. There are two distinct groups of sensory cells. The anterior group is situated internal to the area occupied by the CAP sensilla and the cells of this group lie in the strand or in the hypodermis external to it. The posterior group of cells is peculiar in the manner in which the axons or in some cases the dendrites reflect back towards the joint. The main limb nerve at the $\mathrm{C}-\mathrm{P}$ joint is divided into a large number of smaller nerve trunks which lie close to the receptor. The nerve to the receptor joins the posterior part of the strand distal to the joint, as is the case with $\mathrm{CP}_{2}$ of the walking leg.

\section{Propodite-Dactylopodite Joint (P-D)}

Both limbs have a pair of muscles, an opener and a closer, that serve this joint. There are certain major differences in organization, however, as is evident from the chelate nature of the first three pairs of pereiopods compared with the unchelate condition of the third maxilliped. The fourth and fifth pairs of pereiopods are non-chelate.

a) Walking Leg Receptor. The main strand of PD organ is $3-4 \mathrm{~mm}$ in length and $200-300 \mu$ thick at the widest point. The strand arises from the dorsal face of the closer muscle tendon and passes through the joint into the dactylopodite. The connective tissue strand does not attach distally to a "protuberance" as in Carcinus (Burke, 1954), nor does it insert as a single strand but divides into several fibrous strings that fan out and insert into the hypodermis of the ventral wall.

The nerve supplying the receptor leaves the main leg nerve ventrally and travels along the medial surface of the closer muscle onto the receptor strand. The cells on the strand are similar in shape, size and distribution to those of Carcinus maenas (Burke, 1954) and in number to Cancer irroratus (Hartman and Boettiger, 1967).

b) Third Maxilliped. Despite repeated attempts to locate a receptor at the P.D joint of the maxilliped there is no indication that a receptor exists. Methylene blue and electrophysiological methods have failed to reveal any sign of a receptor and it is concluded that in Homarus there is no PD in this limb.

\section{Comparative Studies}

Nephrops norvegicus. In general the receptors of the walking legs of the Norway lobster closely resemble those of Homarus. At $\mathrm{CP}_{2}$ the methylene blue stained cells associated with CAP are much more prominent and the dendrites follow a curved path after running proximally 


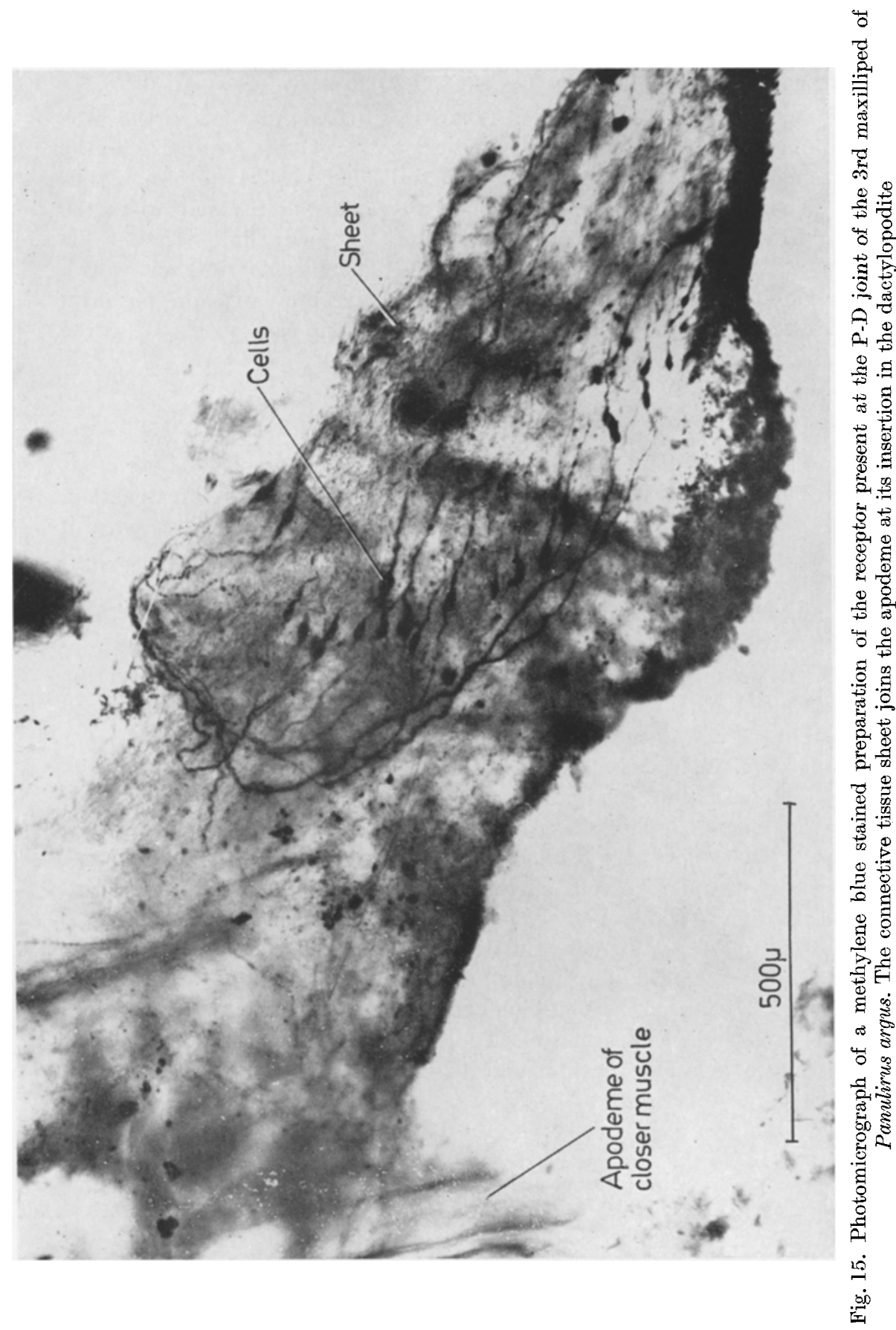


towards the insertion of the small additional muscle; they then turn distally towards the CAP.

Panulirus argus. Results were obtained from the third maxilliped only. The major notable difference between the receptors described for the same limb in Homarus lies in the presence of a PD organ.

1. Ischiopodite-Meropodite Joint $(I-M)$. Only one receptor system, $\mathrm{IM}_{1}$, was observed here but $\mathrm{IM}_{2}$ may also exist. $\mathrm{IM}_{1}$ lies proximal to the joint and is again characteristically different to the more distal receptors as it is in the other limbs described above. A long strand of elastic connective material runs from the apodeme of the productor muscle to end on a small internal spike of cuticle just on the proximal edge of the I-M joint. This strand is connected to the apodeme, and an elastic strand parallel to it by several small tenuous branches of connective tissue.

The sensory cells are arranged in a line along the strand.

2. Meropodite-Carpopodite Joint ( $M-C$ ). The MC proprioceptor is very like that at the $\mathrm{C}-\mathrm{P}$ joint and is allied to the reductor muscle.

3. Carpopodite-Propodite Joint (C-P). At this joint the cells of the single receptor lie distal to the joint, lying on an elastic strand that is attached to the apodeme of the bender muscle. The strand ends by spreading out to insert in the propodite. CAP organs are present.

4. Propodite-Dactylopodite Joint (P.D). Running alongside the leg nerve through this joint into the dactylopodite there is a sheet of tissue that spreads out in a number of branches to insert at several places on the dactyl wall. The apodeme of the closer muscle extends to the proximal border of the dactylopodite where it joins the cuticle. To it is attached the connective tissue strand mentioned above so that the strand is moved whenever the apodeme moves. Running onto the inner face of the connective strand is a collection of bipolar sensory cells (Fig. 15). The axons of these cells are found in the main leg nerve of the propodite, forming a separate branch just proximal to the PD joint and sweeping onto the sheet and reaching the sensory cells just distal to the joint. The dendrites run further in the elastic strand to end distally at some undetermined point. They seem not to extend to the cuticle.

A PD receptor has been observed in the $3 \mathrm{id}$ maxilliped of Palinurus vulgaris but is apparently absent in the same limb of Astacus leptodactylus.

\section{Physiology \\ 1. Walking Leg}

$C-P$ Joint. The pereiopod C-P joint is capable of rotation about the longitudinal axis of the limb and an additional muscle is present at this 

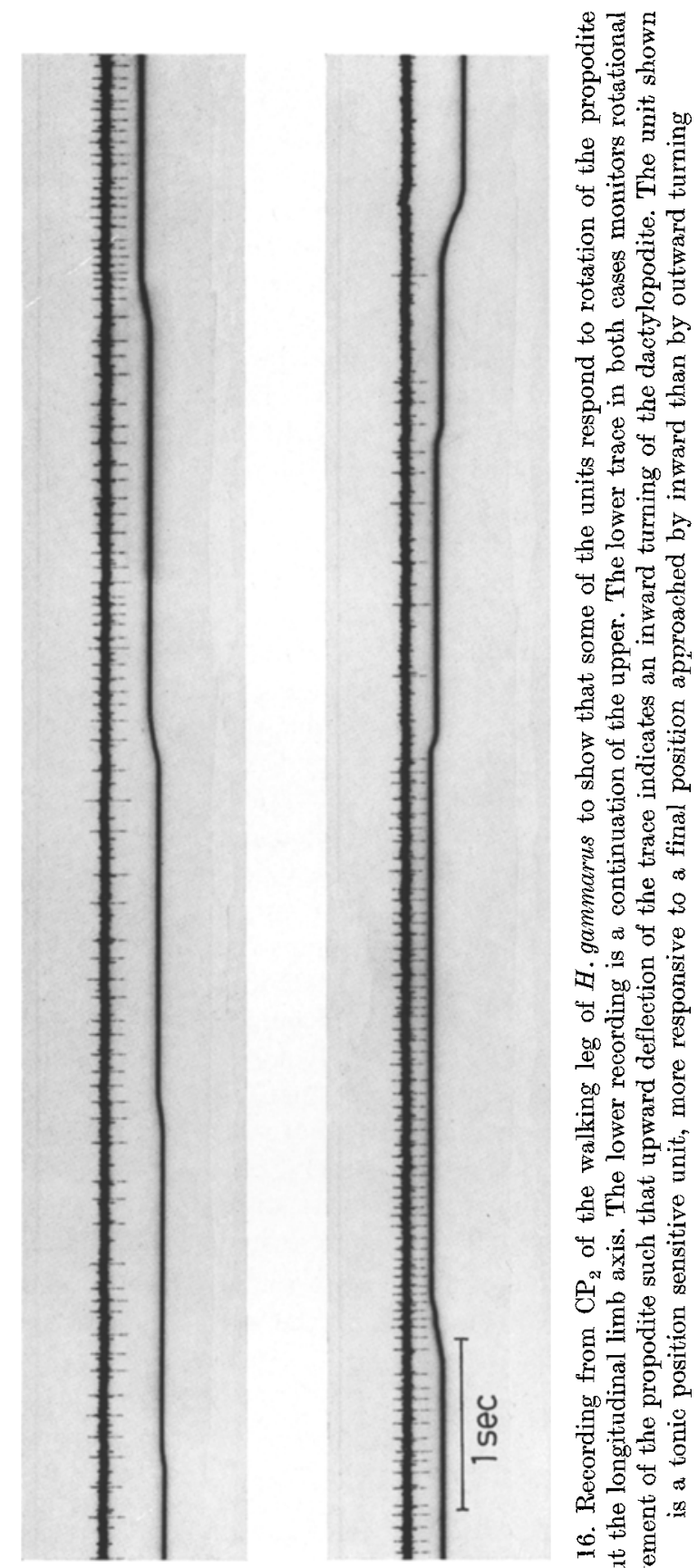

要焉

政密

के क्ष

오용

政政

)

용요

क्षे के

i .

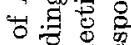

so

ष 8

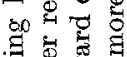

弯

实害起

里焉通

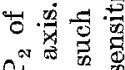

ㄴํㅇㅇㅛ

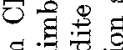

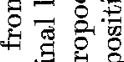

a

寻焉

创

里

0 웜

我亭 
joint. As mentioned previously, the position of distal insertion of this muscle suggests that it is unlikely to produce rotation.

When the joint is reduced or produced $\mathrm{CP}_{1}$ and $\mathrm{CP}_{2}$ are active (as demonstrated by Bush 1965a). If the joint is rotated $\mathrm{CP}_{2}$ shows activity in very few units, frequently only one or two (Fig. 16). These units respond to movement in a clockwise direction (as seen from the proximal end of the left limbs). At rest there is no discharge but the units are positionally sensitive with increasing steps of rotation. There is a short dynamic phase that is evident during movement and a tonic discharge at any given displacement. The return movement leads to cessation of firing during movement, a return of a low tonic discharge when maintained at a set position and no discharge when the limb is again straightened. A short movement in the counter clockwise direction from rest invokes a short discharge during the initial stages of movement but no tonic discharge.

To ascertain whether the additional muscle of this joint was capable of producing rotation as does the third muscle of the Natantia and Stomatopoda (Wiersma and Ripley, 1952) we stimulated the muscle electrically. The preparation for this experiment was made without damage to the joint by sectioning the leg through the carpopodite and the propodite $1 \mathrm{~cm}$ on either side of the joint and fixing the preparation by the carpopodite so that the propodite was suspended freely in sea water. The stimulating electrodes were then lowered into the carpopodite and applied to the head of the additional muscle. By this method we found that stimulation of the additonal muscle alone produced a weak bending of the limb but no detectable rotation.

\section{3rd Maxilliped}

a) $I$ - $M$ Joint Receptors. $\mathrm{IM}_{1}$ contains units unidirectionally sensitive to production of the joint (Fig. $17 \mathrm{~A}$ and B). These sensory cells discharge when the strand is released after stretching (see Table 4). During the experiments recorded in Fig. 17 the I-M joint was moved by application of a micromanipulator-mounted probe to the meropodite. When the joint is reduced the sense cells do not fire but they do upon recoil, thus the strand of $\mathrm{IM}_{1}$ is stretched by reduction and released during production so that the receptor will fire when the muscle contracts. Some of the units are movement and others slow adapting position receptors.

$\mathrm{IM}_{2}$ responds to movement in the opposite direction, that is to reduction of the I-M joint (Fig. $17 \mathrm{C}$ and $\mathrm{D}$ ). If the joint has undergone reduction and is allowed to straighten under elastic recoil the receptor frequency falls dramatically. When movement of the limb stops, a low tonic frequency appears. This frequency rises again on reduction of the joint. The tonic units are position sensitive (Fig. 17C), but have a dynamic 


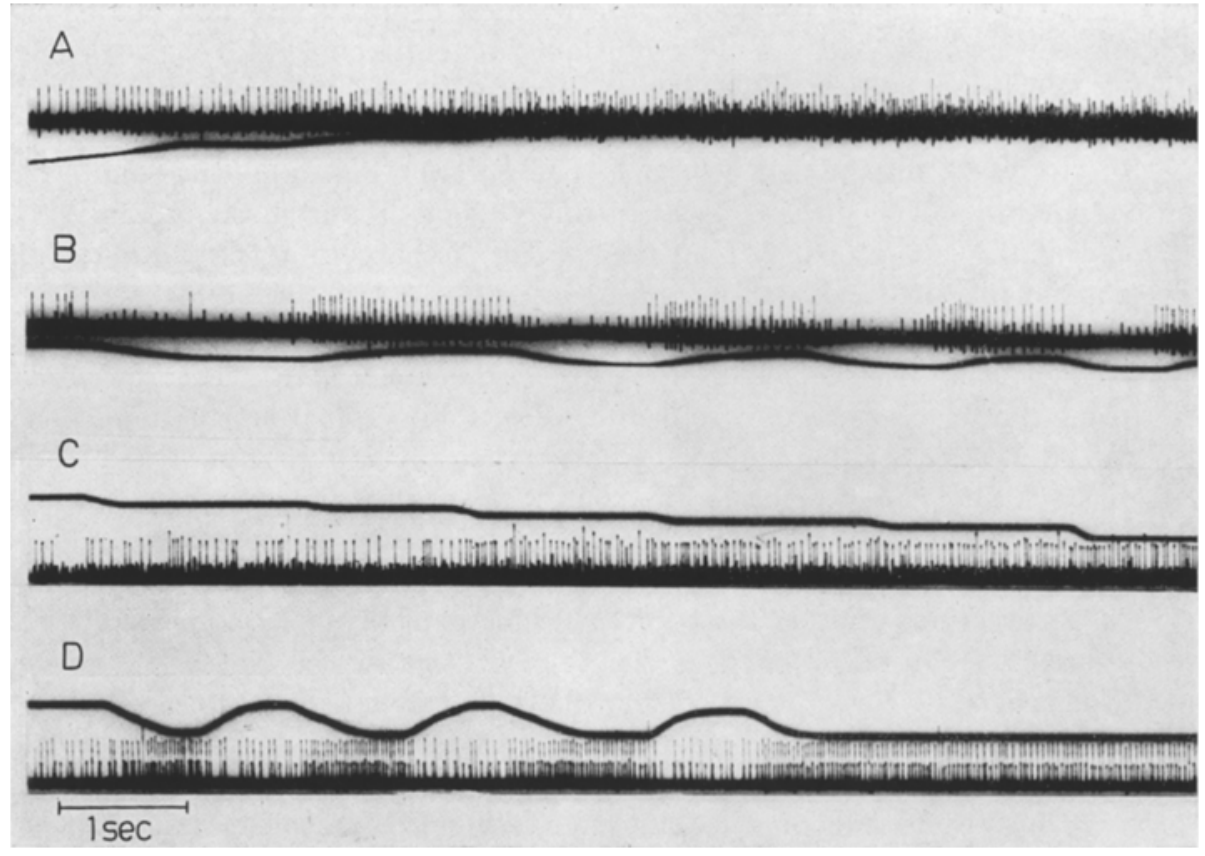

Fig. 17A-D. Recording of the response of the IM receptors of the 3rd maxilliped of $H$. gammarus to passive movement of the meropodite. The lower trace in $\mathrm{A}$ and $\mathrm{B}$ and upper trace in $\mathrm{C}$ and $\mathrm{D}$ monitor joint movement. Downward movement denotes reduction. A. $\mathrm{IM}_{1}$ shows an increasing activity on passive production of the joint. $B$. The units of $\mathrm{IM}_{1}$ are unidirectionally sensitive to production. $\mathrm{C} . \mathrm{IM}_{2}$ has position sensitive units which increase their frequency on reduction. D. The units of $\mathrm{IM}_{2}$ are unidirectionally sensitive to reduction

component also since they fire at a higher frequency during reduction than they do when at rest in a given position.

The IM receptors are attached to the productor muscle and not to its tendon. Hence, as our results were obtained by passive movement and not by muscle stimulation, it is possible that the receptor output in vivo may differ slightly from that which we have recorded.

b) $M-C$ Joint Receptor. The MC receptor, which responds to both stretch and release, is attached to the apodeme of the flexor muscle and is stretched by contraction of the muscle. In our recordings (Fig. 18) the joint was moved by micromanipulator-mounted forceps attached to the flexor apodeme, and the results will be comparable with those obtained by muscle stimulation. The chordotonal organ discharges during movement of the joint in either direction but with more activity evident during extension. Unidirectional units are found which respond to 


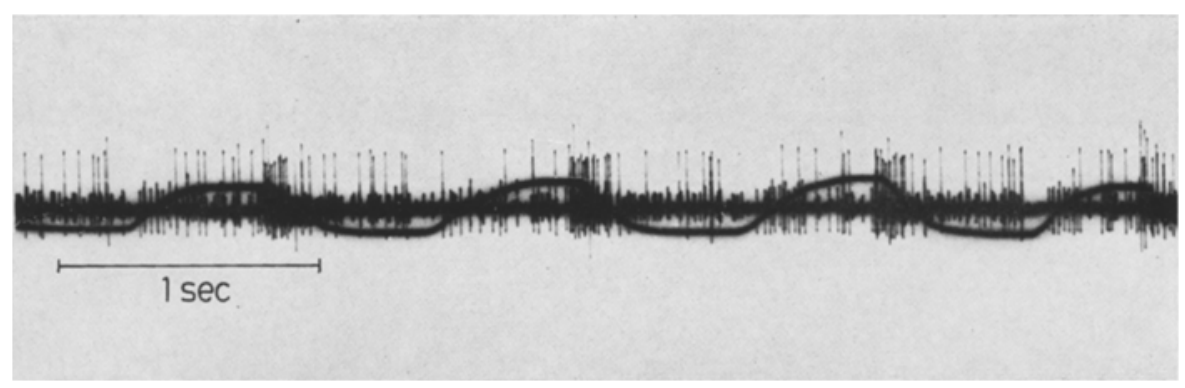

Fig. 18. Recording of the activity of the $\mathrm{MC}$ receptor of the $3 \mathrm{rd}$ maxilliped of $H$. gammarus to movement of the joint produced by manipulation of the flexor muscle apodeme. The lower trace monitors movement of the joint, upward movement denotes flexion. This receptor responds to flexion and to extension of the joint by discharge of unidirectional units

opposing directions of movement and are not active when the limb is stationary. Some units have a tonic phase which does not seem to indicate specific position but merely that the joint is at rest.

c) C.P Joint Receptor. It is difficult to define the movements of the C-P joint in terms of the muscles producing the movement as the musculature is more complex and the joint is capable of a wider range of movements. Unlike the pereiopod the greatest movement at the C-P joint of the 3rd maxilliped occurs in approximately the same plane as the M-C joint and during the experiments shown in Fig. 19 the propodite was moved in this plane only. We therefore use the terms flexion and extension to indicate movement in the same direction as produced by the flexor and extensor of the M-C joint.

The strand of the CP receptor is attached to the ventral bender muscle and is stretched by contraction of the muscle. The sensory cells of the receptor respond to stretching of the strand which will be produced by contraction of the muscle or by passive extension of the joint. There is slight residual activity in the sensory nerve supplying the CP receptor when the joint is maintained in the flexed condition. When the limb is released it moves by elastic recoil back towards a straightened position and during this time the receptor becomes more active, recruiting further units (Fig. 19A). Further extension of the joint, equivalent to dorsal bender contraction brings more units into action. Some of these are position sensitive and usually relate to the spikes of greatest amplitude (Fig. 19B). The smaller units are movement sensors with a tonic phase at rest. When the joint is moved rapidly (Fig. 19C) responses are observed only during extension and not at all during flexion but tonic activity returns during any prolonged stationary period. 


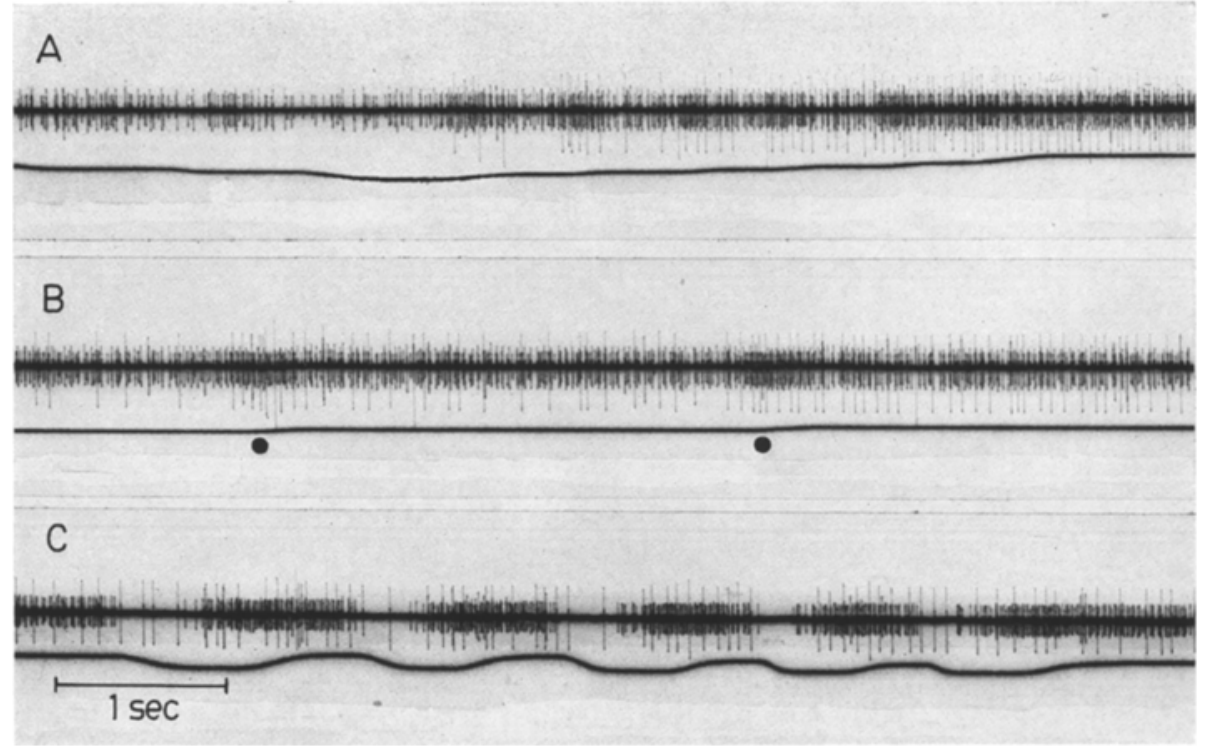

Fig. $19 \mathrm{~A}-\mathrm{C}$. Recording from the CP receptor of the 3rd maxilliped of H. gammarus. The lower trace in each case monitors movement of the joint, a downward movement of the trace indicates flexion produced by movement of the propodite (see text). A. Extension of the flexed limb by elastic recoil. The activity of the receptor is greatly reduced by flexion but activity increases on extension by increased frequency of individual units and recruitment of other units. B. Further extension of the joint in a step fashion (dots indicate onset of movement) demonstrates the presence of position sensitive units. C. The smaller units are movement sensitive responding to extension of the joint and have a tonic phase at rest

As with the receptors of the I-M joint differences in the above results would be expected with movement of the joint produced by muscle stimulation. In vivo the receptor will respond primarily to contraction of the ventral bender and hence activity will be observed during flexion rather than extension (see Table 4).

\section{CAP Sensilla}

Attempts were made to record the response of these sensilla to mechanical stimulation at the C-P joint of the walking leg and at other joints. Recordings were made of the activity in the appropriate sensory nerve and on occasions there seemed to be a response among the smaller units when the sensilla were touched with a fine brush. Similar activity could, however, be observed when the brush was moved close to, but not touching, the CAP sensilla. Hence the observed response 
may have been from other more sensitive sensilla close to the CAP group. No responses that can unequivocally be demonstrated as CAP activity have been recorded.

\section{Discussion}

The macruran walking leg possesses a chordotonal receptor at the T-C joint, whereas it is absent in the brachyuran walking leg (Alexandrowicz and Whitear, 1957). As the chordotonal receptor is the typical decapod limb joint receptor, its presence at the macruran 'T-C joint is more likely to be the basic pattern rather than a specialisation. The retention of this receptor in the macrurans may well be associated with their ability to walk with equal ease forwards and backwards, as well as laterally, as this joint is important in anterior-posterior movement of the limb. The loss of the BI receptor in brachyurans is to be expected in view of the fusion of the joint. The $\mathrm{IM}_{2}$ receptor is not lost in the Brachyura, but becomes involved in the $\mathrm{MCO}$ complex as $\mathrm{MCO}_{2}$ (Clarac, 1968a). The total number of chordotonal organs, therefore, remains the same but involvement of this IM receptor in monitoring movement of the M-C joint indicates the increased importance of this joint in lateral movements.

The strand organs of the crab walking legs adopt different forms in the macruran limbs. $\mathrm{MC}_{2}$ is a strand, but the disposition of the cells differs markedly from that of the brachyuran limb. $\mathrm{CP}_{2}$ is in the form of a sheet and PD, the cells of which are similar to that of brachyurans in disposition, has a broader and more diffuse strand. The sheetlike receptors $\mathrm{CP}_{1}$ and $\mathrm{MC}_{1}$, however, are similar to those in Carcinus (Whitear, 1962).

The macruran 3rd maxilliped and 2nd pereiopod show several differences. Like the brachyuran walking leg, the macruran 3rd maxilliped lacks a chordotonal receptor at the T-C joint. Movement of this joint may be of reduced importance as possible anterior-posterior movement is restricted by the chelae. The loss of the BI receptor may again be correlated with the fusion of this joint. A major difference is the absence of a myochordotonal organ (MCO) in the 3rd maxilliped. Evoy and Cohen (1969) have shown that the input from the myochordotonal organ excites its own receptor muscle on joint movements away from the set rest position. They suggest that interactions of this input with the MC chordotonal inputs (which affect the receptor muscle in the same sense as the main flexor) provide the system with a dynamically determined reference point for the basic postural position. It is not difficult to see the value of this system as the MC joint of the legs will often be subject to environmental variations (e.g. change of load on one limb will affect the load on the others). The third maxilliped, however, is not subject 
to such changing loads and in life tends to be held in set positions. In this appendage the M-C and C-P joints have but single receptors and these, in their structure, position relative to the joint and association with the CAP sensilla, correspond to $\mathrm{CP}_{2}$ and $\mathrm{MC}_{2}$ of the walking leg. Thus, the more complex $\mathrm{CP}_{1}$ and $\mathrm{MC}_{1}$ are absent. It is interesting that $\mathrm{CP}_{1}$ and $\mathrm{MC}_{1}$ are associated with the bender and flexor muscles respectively, and do not cross the joint, hence not one but three receptors associated with muscles are absent in the 3rd maxilliped. This difference, by analogy with the $\mathrm{MCO}$, may indicate the value of $\mathrm{CP}_{1}$ and $\mathrm{MC}_{1}$ in the locomotory processes. It would be interesting to compare the effect on walking of the ablation of $\mathrm{MCO}, \mathrm{MC}_{1}$ and $\mathrm{CP}_{1}$ with the ablation of $\mathrm{MC}_{2}$ and $\mathrm{CP}_{2}$. The $\mathrm{PD}$ receptor is apparently absent in some macrurans e.g. Homarus gammarus and Nephrops norvegicus but is present in Panulirus argus. This difference may well reflect the difference in use of this limb by Panulirus which uses its 3rd maxilliped vigorously to clasp its prey in a scissor-like action (D. M. Maynard private communication). Homarus gammarus is apparently capable of catching active prey such as fish, presumably by means of its chelae (Herrick, 1895) whereas Panulirus lacks the large chelae (see Table 5).

Table 5. Presence or absence of receptors at the various joints of the limbs investigated in this paper. Muscle receptor organ (MRO), elastic strand (ES), myochordotonal organ (MOO)

\begin{tabular}{lllll}
\hline Receptor & $\begin{array}{l}\text { Carcinus } \\
\text { walking leg }\end{array}$ & $\begin{array}{l}\text { Nephrops and } \\
\text { Homarus } \\
\text { walking leg }\end{array}$ & $\begin{array}{l}\text { Nephrops and } \\
\text { Homarus } \\
\text { 3rd maxilliped }\end{array}$ & $\begin{array}{l}\text { Panulirus } \\
\text { 3rd maxilliped }\end{array}$ \\
\hline TC MRO & Yes & Yes & Yes & Not known \\
TC ES & Yes & Yes & Yes & Not known \\
MCO 1 & Yes & Yes & No & No \\
MCO 2 & Yes & No & No & No \\
\hline
\end{tabular}

Chordotonal

Type

\begin{tabular}{lllll} 
TC & No & Yes & No & Not known \\
CB & Yes & Yes & Yes & Not known \\
BI & No joint & Yes & No joint & No joint \\
IM1 & Yes & Yes & Yes & Yes \\
IM2 & No & Yes & Yes & Not known \\
MC1 & Yes & Yes & No & No \\
MC2 & Yes & Yes & Yes & Yes \\
CP1 & Yes & Yes & No & No \\
CP2 & Yes & Yes & Yes & Yes \\
PD & Yes & Yes & No & No \\
\hline
\end{tabular}


From a general survey it appears that the receptors form flat sheets where the articulation of the joint is of a looser nature, or where the musculature can produce movement in more than one plane $\left(\mathrm{CP}_{2}\right.$ of the walking leg, MC, CP and PD of the 3rd maxilliped). The sheets may represent an early stage in strand development having been formed by a condensation of a more diffuse system of cells and connective tissue fibres. Comparatively simple receptor structures that consist of cells with lengthy strands of connective tissue inserting via scolopidia at the cuticle have been described in the isopod Ligia by Alexander (1969). Not all of these receptors need be primitive in form, however, as flexibility may be due to specialised requirements rather than regression. This is most probably true of the C-P joint, particularly of the walking leg where flexibility of the joint is accompanied by differences in the musculature by means of which the joint can be moved in more than one plane.

The physiological results obtained confirm that the units in the chordotonal organs examined resemble those described in the Brachyura. Examination of tables 2 and 3 shows that comparable receptors in the brachyuran and macruran walking legs contain elements responding to the same gross stimulations of stretch and release. For the maxilliped, however, differences in the form and function of the appendages have clearly been reflected in functional changes in the receptors. For example, $\mathrm{CP}$, which is analagous to $\mathrm{CP}_{2}$ of the walking legs, responds in a directly opposite way to that receptor. More significantly MC, which is analagous to $\mathrm{MC}_{2}$ of the walking legs, responds to both stretch and release instead of release only. This probably reflects the importance of the MC joint in the function of the maxilliped. This fact also follows from Wiersma's (1958) investigation of sensory collecting neurones where he found that the marker unit number 1 had an important input from the maxilliped M-C joint. The only other interneurones with important inputs from the maxilliped joints were either specifically activated by the basal joints or activated by many joints.

The investigation of the role of these proprioceptors in the posture and movement of decapod appendages now requires that they be studied in the almost intact animal. This can either be carried out on restrained animals to examine the involvement of specific receptors (see Evoy and Cohen, 1969) or by the study of the unrestrained animal with implanted electrodes. The latter approach has been used successfully in the study of locust walking and the effect of receptor ablation (Usherwood, Runion and Campbell, 1968; Runion and Usherwood, 1968) and in the study of crab walking (Atwood and Walcott, 1965; Barnes, private communication 1970).

The C.P Joint and the Additional Muscle. The presence of the additional muscle, previously undescribed in this group of decapods, is 
reminiscent of the Stomatopoda and Natantia which also possess a supernumerary muscle at the C-P joint. The muscle present in these groups produces rotation of the propodite (Wiersma and Ripley, 1952) whereas the additional muscle of Homarus gammarus, does not. This is demonstrated by consideration of the structure of the joint and the insertion of the muscle and the results of stimulation experiments. Stimulation of the additional muscle alone produces weak bending at the joint in the straightened limb, but it seems probable that this muscle acts in conjunction with the stretcher since it shares a common innervation. The stretcher, however, is its apparent antagonist. Sherman and Atwood in a personal communication state that this is a slow muscle that has 1 excitor axon and 1 inhibitor shared with the stretcher. Excitation brings about slight rotation initially, followed by bending once the articulation points have met provided the tension developed is sufficient.

The C-P joint, however, is capable of rotation and this is apparently a common feature of the pereiopods of macrurans and anomurans, most of which posses only two muscles at this joint. Rotation has been shown to be achieved by activity of the bender muscle in the anomuran Dardanus asper and the brachyuran Dromidiopsis dormia (Wiersma and Ripley, 1954). It is most probable that this is the mechanism employed in other reptantian decapods including those with an additional muscle and that this muscle has a different function from the third muscle of the Natantian decapods. What this may be is at present only a matter for speculation. It is noticeable that the C-P joint of the pereiopod is very flexible (Figs. 2 and 4 ) but in the walking animal the joint is moved very little regardless of the animal's direction of movement. It is possible that the function of the additional muscle is to stiffen the joint when it is supporting weight, a function which must be achieved in species with two muscles, by maintained tension in the bender and stretcher.

The 3rd maxilliped does not bear weight and hence does not require to be stiffened at the C-P joint. Here the three muscles are more uniform in size and all are involved in movement of the propodite.

The CAP sensilla. The groups of sensilla found distal to the C.P and M-C joints of both the 3rd maxilliped and the pereiopod and the I-M joint of the pereiopod have been renamed; cuticular articulated peg (CAP) sensilla. These sensilla originally described by Wiersma (1959) as being pits in the cuticle were referred to by him as "slit sensilla". This choice of name was unfortunate because of its possible association with the lyriform organs of arachnids. The lyriform organs are elongated cuticular slits a few micra wide and 10 to $200 \mu$ long with no external projections (see Bullock and Horridge, 1965). The articular membrane of the CAP sensilla is approximately circular and bears a peg the length of which is variable. Alexandro- 
wicz (1969) states that the sensilla are innervated by the cells of the respective receptors ( $\mathrm{MCO}, \mathrm{MC}_{2}$ and $\mathrm{CP}_{2}$ in the pereiopod, $\mathrm{MC}$ and $\mathrm{CP}$ in the 3rd maxilliped). Evidence from methylene blue stained preparations in Homarus gammarus suggests that, although the CAP sensilla are innervated by the same nerve trunk as the chordotonal receptor, the two groups of cells are separate. This observation is supported by Clarac and Masson (1969) who have shown that the MCO of Astacus leptodactylus is innervated by a separate group of cells from those of the CAP sensilla of the IM joint. Alexandrowicz (1969), however, considers that the cells of the respective chordotonal organs terminate in the CAP sensilla. Unfortunately methylene blue does not stain the terminal processes of the dendrites sufficiently well for dendrites to be traced for sufficient distance to confirm this.

From their structure, one would suspect the normal stimulus of the CAP sensilla to be movement of the peg and their location is such that the articular membrane of the joint will make contact when the joint is flexed except in the case of the I-M joint where only about half of the sensilla make contact with the membrane even at full reduction. Attempts to record the response of the sensilla to peg movement were inconclusive. The main difficulty is that the sensory nerve to the CAP sensilla and chordotonal organ innervates other sensilla in the area (see Fig. 13). As it has been shown that some types of sensilla are very sensitive to water currents and other surface disturbances (Laverack, $1962)$ it is difficult to be certain that any activity observed did not arise from sensilla other than the CAP sensilla.

An "Autotomy Control" Receptor? We have included in this paper a description of a previously undescribed receptor located in the basipodite of the 3rd maxilliped and pereiopods. In the 3rd maxilliped the receptor is situated close to the flagellum base, but it does not cross the B-F joint and is not attached to either of the flagellar muscles so it can only be involved in monitoring of flagellar movement if sufficient movement of the hypodermis occurs between the joint and the receptor. It is thus unlikely that monitoring B-F joint movement is it's only function if indeed it is the function at all. This argument is supported by the presence of a receptor in the pereiopod which shows no sign of regression although there is no flagellum.

In the $3 \mathrm{rd}$ maxilliped the receptor lies just proximal to the line of fusion of the B-I joint which structurally resembles the plane of autotomy in the brachyuran pereiopod. Wood and Wood (1932) have shown that the 3rd maxilliped can be artificially autotomised, but do not state where the breakage occurred. The receptor of the lobster pereiopod lies just proximal to the B-I joint and a similar receptor is present in Carcinus maenas just proximal to the plane of autotomy. 
Wood and Wood (1932) describe the plane of weakness in the pereiopod of Homarus vulgaris $(=H$.gammarus) as lying in the ischiopodite close to the B.I joint. The structure to which they refer is a line of flexible uncalcified cuticle and bears no similarities to the fracture line observed in the macruran 3rd maxilliped or brachyuran pereiopod. Observation of animals in our tanks which had lost pereiopods, presumably due to fighting, showed that in more than 40 cases observed, all of the legs had broken at the B-I joint and not in the ischiopodite. To determine if this was the true plane of breakage, twenty animals (Homarus gammarus) were suspended in sea water by their left 2 nd pereiopod for rperiod of $\mathbf{2 4}$ hours. Only four animals underwent autospasy but in these ases the breakage occurred through the B-I joint. Hence in the pereiopod of Homarus gammarus the receptor is just proximal to the plane of breakage.

In Homarus gammarus the anterior insertion of the strand is associated with an area of soft cuticle which is easily deformed and it is probable that this receptor may respond to cuticular deformation. The muscle which produces autotomy, and presumably aids autospasy is the anterior levator of the basipodite which is functional in normal limb movement. The animal will require knowledge of any strains being imposed upon the breakage plane to prevent accidental loss of limbs during normal or rapid movements and it seems possible that this receptor may fulfil this requirement.

\section{References}

Alexander, C. G.: Structure and properties of mechanoreceptors in the pereiopods of Ligia oceanica. Comp. Biochem. Physiol. 29, 1197-1206 (1969).

Alexandrowicz, J. S.: Receptor organs in the coxal region of Palinurus vulgaris. J. mar. biol. Ass. U.K. 47, 415-432 (1967).

- Ann. Rep. Council Marine Biol. Ass. U. K., 25-26 (1969).

- Whitear, M.: Receptor elements in the coxal region of Decapoda Crustacea. J. mar. biol. Ass. U. K. 36, $603-628$ (1957).

Atwood, H. L., Walcott, B.: Recording of electrical activity and movement from legs of walking crabs. Canad. J. Zool. 43, 657-665 (1965).

Bullock, T. H., Horridge, G. A.: Structure and function in the nervous systems of invertebrates, vol. 2, p. 1058. San Francisco: W. H. Freeman and Co. 1965.

Burke, W.: An organ for proprioception and vibration sense in Carcinus maenas. J. exp. Biol. 31, 127-137 (1954).

Burrows, M., Willows, A. O.D.: Neuronal co-ordination of rhythmic maxilliped beating in brachyuran and anomuran curstacea. Comp. Biochem. Physiol. 31, 121-136 (1969).

Bush, B. M. H.: Proprioceptive reflexes in the legs of Carcinus maenas. J. exp. Biol. 39, 89-105 (1962).

- A comparative study of certain limb reflexes in decapod crustaceans. Comp. Biochem. Physiol. 10, 273-290 (1963). 
Bush, B.M.H.: Proprioception by chordotonal organs in the mero-carpopodite and carpopropodite joints of Carcinus maenas legs. Comp. Biochem. Physiol. 14, 185-199 (1965a).

- Proprioception by the coxo-basal chordotonal organ, CB, in the legs of the crab Carcinus maenas. J. exp. Biol. 42, 285-298 (1965b).

- Leg reflexes from chordotonal organs in the crab Carcinus maenas. Comp. Biochem. Physiol. 15, 567-587 (1965c).

Clarac, F.: Proprioceptor anatomy of the ischiopodite-meropodite region in legs of the crab Carcinus mediterraneus. Z. vergl. Physiol. 61, 203-223 (1968a).

- Proprioception by the ischio-meropodite region in legs of the crab Carcinus mediterraneus C. Z. vergl. Physiol. 61, 224-245 (1968b).

- Masson, C.: Anatomie comparée des propriocepteurs de la région basi-ischioméropodite chez certains crustacés décapodes. $Z$. vergl. Physiol. 65, 242-273 (1969).

Evoy, W. H., Cohen, M. J.: Sensory and motor interactions in the locomotor reflexes of crabs. J. exp. Biol. 51, 151-170 (1969).

Finlayson, L. H.: Proprioceptors in the invertebrates. Symp. zool. Soc. Lond. 28, $217-249$ (1968).

Hartman, H. B., Boettiger, E. G.: The functional organisation of the propusdactylus organ in Cancer irroratus (Say). Comp. Biochem. Physiol. 22, $651-663$ (1967).

Herrick, F. H.: The American lobster. Washington: Government Printing Office 1895.

Laverack, M. S.: Responses of cuticular sense organs of the lobster. Homarus vulgaris (Crustacea). I. Hair-peg organs as water current receptors. Comp. Biochem. Physiol. 5, 319-325 (1962).

- Ardill, D. J.: The innervation of the aesthetase hairs of Panulirus argus. Quart. J. micr. Sci. 106, 45-60 (1965).

Runion, H. I., Usherwood, P. N. R.: Tarsal receptors and leg reflexes in the locust and grasshopper. J. exp. Biol. 49, 421-436 (1968).

Sandeman, D. C.: Proprioceptor organ in the antennules of Squilla mantis. Nature (Lond.) 201, 402-403 (1963).

Schmidt, W.: Die Muskalatur von Astacus fluviatilus (Potamobius astacus L.). Z. wiss. Zool. 113, 165-251 (1915).

Shelton, R. G. J., Laverack, M. S.: Observations on a redescribed erustacean cuticular sense organ. Comp. Biochem. Physiol. 25, 1049-1059 (1968).

Usherwood, P.N.R., Runion, H. I., Campbell, J. I.: Structure and physiology of a chordotonal organ in the locust leg. J. exp. Biol. 48, 305-323 (1968).

Whitear, M.: The fine structure of crustacean proprioceptors. I. The chordotonal organs in the legs of the shore crab, Carcinus maenas. Phil. Trans. 245, $291-325$ (1962).

Wiersma, C. A. G.: On the functional connections of single units in the central nervous system of the crayfish Procambarus clarkii (Girard). J. comp. Neurol. 110, 421-471 (1958).

- Movement receptors in decapod crustacea. J. mar. biol. Ass. U. K. 38, 143-152 (1959).

- Boettiger, E. G.: Unidirectional movement fibres from a proprioceptive organ of the crab, Carcinus maenas. J. exp. Biol. 36, 102-112 (1959).

- Ripley, S. H.: Innervation patterns of crustacean limbs. Physiol. comp. ('s-Grav.) 2, 391-405 (1952).

- - Further functional differences between fast and slow contraction in certain crustacean muscles. Physiol. comp. ('s-Grav.) 3, 327-336 (1954). 
384 Wales, Clarac, Dando and Laverack: Macruran Limb Joint Receptors

Wood, F. D., Wood, H. E.: Autotomy in decapod crustacea. J. exp. Zool. 62, 1-49 (1932).

Wyse, G. A., Maynard, D. M.: Joint receptors in the antennule of Panulirus argus. J. exp. Biol. 42, 521-535 (1965).

Dr. W. Wales and

Prof. Dr. M. S. Laverack

Gatty Marine Laboratory

University of St. Andrews

St. Andrews/Scotland

Dr. M. R. Dando

Department of Zoology

University of Michigan

Ann Arbor, Michigan 48104/U.S.A.
Dr. F. Clarac

Institut de Neurophysiologie

et de Psychophysiologie de C.N.R.S.

31 Chemin Joseph Aiguier

F-13 Marseille (9e)/France 